\title{
The state of the art of institutional capacity: a scoping review of the literature in Portuguese
}

DOUGLAS GOMES MARTINS ${ }^{1}$

\author{
${ }^{1}$ Instituto Federal de Educação, Ciência e Tecnologia do Pará (IFPA), Paragominas - PA, Brasil
}

\begin{abstract}
Government institutional capacity is generally understood as the set of skills observed in governmental institutions, which are necessary to achieve public goals. However, there are numerous conceptualizations in the literature. This study aimed to breakdown institutional capacity, into its constitutive dimensions. The search for proxies active in the Brazilian context and that empirically allow measuring the operationalization of institutional capacity took place after an extensive literature review from three perspectives: a) analysis of the network of authors, identifying the main researchers exploring the topic of institutional capacity, b) a descending hierarchical classification technique aimed to distinguish the classes (if any) that represent distinct forms of discourse on the concept of institutional capacity, and c) the word tree technique, which identified connections between the keyword institutional capacity, and the entire textual corpus. We conclude that it is possible to advance empirically in studies on institutional capacity by examining the government's fiscal, administrative, and political dimensions.
\end{abstract}

Keywords: Institutional capacity. Scooping review. Descending hierarchical classification. Network analysis. Word tree.

\section{O estado da arte da capacidade institucional: uma revisão sistemática da literatura em língua portuguesa}

\section{Resumo}

Genericamente, a capacidade institucional $(\mathrm{Cl})$ dos governos é compreendida como o conjunto de capacidades das instituições para a consecução dos objetivos públicos. Contudo, as conceituações disponíveis na literatura mostram grande variação. O objetivo deste estudo consistiu na desagregação do constructo capacidade institucional em suas dimensões constitutivas. A busca de variáveis (proxies) atinentes ao contexto brasileiro e que possibilitem, empiricamente, a mensuração e operacionalização da $\mathrm{Cl}$ se deu mediante extensa revisão de literatura a partir de 3 perspectivas: a) a análise da rede de autores teve por objetivo elucidar quais são o(s) pesquisador(es) de referência nos estudos sobre a $\mathrm{Cl}$; b) a técnica de classificação hierárquica descendente (CHD) teve por objetivo distinguir, caso existam, as classes que representam formas distintas de discurso sobre o conceito de $\mathrm{Cl}$; e c) a técnica de árvore de palavras possibilitou a visualização das conexões identificadas entre a palavra-chave, capacidade institucional, e todo o corpus textual. Conclui-se que é possível avançar empiricamente nos estudos sobre a $\mathrm{Cl}$ a partir do exame das dimensões fiscal, administrativa e política dos governos.

Palavras-chave: Capacidade institucional. Revisão sistemática. Classificação hierárquica descendente. Análise de redes. Árvore de palavras.

\section{El estado del arte de la capacidad institucional: una revisión sistemática de la literatura en portugués}

\section{Resumen}

En general, la capacidad institucional de los gobiernos se entiende como el conjunto de capacidades que las instituciones tienen para lograr los objetivos públicos. Sin embargo, las conceptualizaciones presentes en la literatura muestran una gran variación. El objetivo de este estudio consistió en el desglose del constructo "capacidad institucional", en sus dimensiones constitutivas. La búsqueda de variables proxy relacionadas con el contexto brasileño y que permitan empíricamente la medición y operacionalización de la capacidad institucional se llevó a cabo mediante una extensa revisión de la literatura desde tres perspectivas: 1) el análisis de la red de autores, cuyo objetivo fue dilucidar cuáles son los investigadores de referencia en los estudios sobre capacidad institucional; 2) la técnica de clasificación jerárquica descendente cuyo propósito fue distinguir, si existieran, las clases que representan formas distintas de discurso sobre el concepto de capacidad institucional; y 3) la técnica de árbol de palabras, que permitió ver las conexiones identificadas entre la palabra clave, la capacidad institucional y todo el corpus textual. Se concluye que es posible avanzar empíricamente en los estudios sobre capacidad institucional examinando las dimensiones fiscal, administrativa y política de los gobiernos.

Palabras clave: Capacidad institucional. Revisión sistemática. Clasificación jerárquica descendente. Análisis de redes. Árbol de palabras. 


\section{INTRODUCTION}

As the interest in studying the State - as an actor or an institution - gained prominence from the large number of academic publications in the most diverse fields of knowledge, the institutional capacity (IC) theme achieved relevance. In Latin America, the initial studies on IC were closely related to the second generation of the 1990s State reforms and were guided by the principles that run the management administration model, which inspired these reforms (Huerta, 2008; Skocpol, 1985).

Thus, academic evidence suggests that the IC concept emerged in the 1980s, based on the analysis of international financing agencies (such as the World Bank) whose purpose was to appraise some countries' efficiency in applying the investments granted by these international development institutions. Therefore, the IC concept was associated, at first, with the conceptions of organizational reengineering techniques, with emphasis on the internal structures of organizations (Huerta, 2008; Lessik \& Michener, 2000; Mizrahi, 2004).

According to Mizrahi (2004), even though the concept has drawn the attention of governments and academia, there is still little agreement on how to define, operationalize, measure and improve IC, due to the scope of this concept. In addition to this scenario, the fact that there is a vast array of conceptualizations and measurement methodologies for the studies involving IC should also be emphasized (Cingolani, 2013).

This finding is corroborated by the analysis of Brazilian studies that address the IC theme: Lubambo and Coutinho (2004); Silva (2015); Veloso, Monasterio, Vieira and Miranda (2011). Depending on the study, the IC is associated with: a) the degree of government governance (through the promotion of participatory channels; the transparency of government actions, etc.); b) management capacity (prioritizing the strands of: finance; capital and infrastructure; people; and information technology); and c) the State performance in defining and implementing development strategies and in transforming reality.

Therefore, the development of this study aimed to answer the following questions:

- What is the current state of the art of studies on institutional capacity in the Brazilian academy?

- Is it possible to empirically advance in studies on institutional capacity in order to understand what the main constitutive elements that can influence it are?

Thus, the objective of this study was to deepen the understanding of the IC concept, by identifying the way it was approached by the scientific production of articles in Brazil, within the scope of public administration, over a period of 10 years (from 2008 to 2018).

The scoping review was supported by lexicographic analysis and network analysis software programs: IRAMUTEQ, MAXQDA and Pajek. The lexicographic analysis made it possible to subdivide the IC construct into its constituent parts, evidencing the Brazilian context relevant variables (proxies) which empirically allow the IC measurement and operationalization. The analysis of author networks showed the state of the art and the existence of eventual reference researchers in the studies on IC; it also enabled the verification of connections among the bibliographic references of the articles selected for the integrative review. The interactive word tree technique, on its turn, provided the visualization of the connections identified among the keyword, the institutional capacity, and the entire textual corpus selected for the literature review.

This article is organized as follows: a) after this introduction, there is b) a brief theoretical-conceptual discussion of the literature review scope; c) the third section describes the proposed methodologies as well as the integrative review on IC operationalization; d) the results are discussed in the fourth section; and e) the text ends with our conclusions and the practical implications of this research.

\section{THEORETICAL FRAMEWORK}

\section{A brief review on institutional capacity}

Etymologically, the noun capacity derives from the Latin word "capacitas" and relates to someone's or something's ability or aptitude to perform a task, it is also associated with the concept of efficiency. The term institutional, also of Latin origin, comes from institutio, which means creation, formation (Glosbe, 2018). In academia, the concatenation of these two terms is closely linked to public administration, and their meaning is linked to the state's capacity to develop and implement public policies. 
There are reference studies on the IC concept, among the major ones, Evans (1995)' work stands out. The author analyzes the capacity of States based on certain characteristics, such as the quality of public bureaucracy, the autonomy level of such bureaucracy in the relationship with the structures that permeate it, and the typology of states' behavior. In turn, Painter and Pierre (2005) examine IC from the perspective of governments' abilities to make smart choices and define strategies, with a view to efficient allocation of resources. Huerta (2008), on the other hand, relates IC to the search for efficiency, based on a set of procedures that enable public administrations to have an adequate IC to optimize their functions, adapt their institutions, formulate and implement policies and be responsible (accountable), within the scope of a public management system.

Based on these theoretical frameworks, it can be noted that the point of agreement on the IC definition consists of the establishment of a causal relationship between the institutions and the results desired by them, which means that having an adequate IC determines the good performance of governments. Within the scope of this research, IC relates to government performance and comprises the set of capacities necessary for it to attain its institutional objectives (Cruz et al., 2011).

There is an effort in the literature to measure IC in quantitative terms, even though part of the studies has a qualitative predominance. Articles that empirically measured IC were searched as a means to verify whether there is agreement concerning the variables used and, consequently, in the definition of variables for the construct. The result of this research, which involved the last decade, is shown in Box 1.

\section{Box 1}

Authors who empirically operationalize the measurement of institutional capacity for 2009-2019

\begin{tabular}{|c|c|c|}
\hline Author & $\begin{array}{l}\text { Variables } \\
\text { used }\end{array}$ & $\begin{array}{l}\text { Title of the article and } \\
\text { year of publication }\end{array}$ \\
\hline $\begin{array}{l}\text { 1. Kris Hartley } \\
\text { and J. Zhang }\end{array}$ & $\begin{array}{l}\text { Communication levels; intra and interinstitutional consultation } \\
\text { and coordination; finance and personnel levels; transparency; } \\
\text { presence of the rule of law; access to information; adequate tax } \\
\text { system to finance programs and projects. }\end{array}$ & $\begin{array}{l}\text { Measuring policy capacity through governance } \\
\text { indices, } 2016 .\end{array}$ \\
\hline $\begin{array}{l}\text { 2. Gomide } \\
\text { and Boschi }\end{array}$ & $\begin{array}{l}\text { Efficient bureaucracies; refitting the production matrix; fostering } \\
\text { development; adoption of social inclusion policies with distributive } \\
\text { effects; expansion of democracy. }\end{array}$ & $\begin{array}{l}\text { Capacidades estatais para políticas públicas em } \\
\text { países emergentes: (des)vantagens comparativas } \\
\text { do Brasil, } 2016 \text {. }\end{array}$ \\
\hline $\begin{array}{l}\text { 3. Luciana } \\
\text { Cingolani }\end{array}$ & $\begin{array}{l}\text { Combination of the following state power dimensions: a) coercive } \\
\text { (property rights); b) fiscal; c) administrative; d) transforming or } \\
\text { industrializing; e) relational/territorial coverage; f) legal; g) policy. }\end{array}$ & $\begin{array}{l}\text { The state of State capacity: a review of concepts, } \\
\text { evidence and measures, } 2013 \text {. }\end{array}$ \\
\hline $\begin{array}{l}\text { 4. Lindvall } \\
\text { and Teorell }\end{array}$ & $\begin{array}{l}\text { Fiscal capacity; specialized bureaucracy; information; coercion; } \\
\text { incentives and advertising. }\end{array}$ & $\begin{array}{l}\text { State capacity as power: a conceptual framework, } \\
2016 .\end{array}$ \\
\hline $\begin{array}{l}\text { 5. Pires and } \\
\text { Gomide }\end{array}$ & $\begin{array}{l}\text { Bureaucracy specialization; dialogue between government and } \\
\text { society; performance; analysis of results. }\end{array}$ & $\begin{array}{l}\text { Governança e capacidades estatais: uma análise } \\
\text { comparativa de programas federais, } 2015 \text {. }\end{array}$ \\
\hline $\begin{array}{l}\text { 6. Sandra } \\
\text { Gomes }\end{array}$ & $\begin{array}{l}\text { Fiscal (own tax revenue and resources from intergovernmental } \\
\text { transfers); administrative (staff qualification, organizational structure, } \\
\text { results of implementation); policy (accountability, transparency, } \\
\text { communication channels, presence of regulatory bodies). }\end{array}$ & $\begin{array}{l}\text { The multi-faceted debate on decentralization and } \\
\text { collective welfare, } 2010 .\end{array}$ \\
\hline $\begin{array}{l}\text { 7. Angélica } \\
\text { Huerta }\end{array}$ & $\begin{array}{l}\text { Administrative capacity (rule of law, specialization of bureaucracy, } \\
\text { structure and distribution of functions and responsibilities, availability } \\
\text { of financial resources, relationship, coordination and intergovernmental } \\
\text { collaboration); political capacity (channels of communication and } \\
\text { political participation, transparency and accountability). }\end{array}$ & $\begin{array}{l}\text { Una ruta metodológica para evaluar la capacidad } \\
\text { institucional, } 2008 .\end{array}$ \\
\hline $\begin{array}{l}\text { 8. André Luís } \\
\text { Nogueira }\end{array}$ & $\begin{array}{l}\text { Use of administrative, fiscal and political indicators. Respectively: } \\
\text { organizational structure of state governments, expenses paid in the } \\
\text { social assistance function and presence of public policy councils. }\end{array}$ & $\begin{array}{l}\text { Os estados no SUAS: uma análise da capacidade } \\
\text { institucional (Cl) dos governos estaduais, } 2015 .\end{array}$ \\
\hline $\begin{array}{l}\text { 9. Helen J. } \\
\text { Addison }\end{array}$ & $\begin{array}{l}\text { Coordination capacity (bureaucratic arrangements and their } \\
\text { collaborative links with dominant civil society organizations), } \\
\text { implementation capacity (service provision) and accountability capacity. }\end{array}$ & $\begin{array}{l}\text { Is administrative capacity a useful concept? Review of the } \\
\text { application, meaning and observation of administrative } \\
\text { capacity in political science literature, } 2009 \text {. }\end{array}$ \\
\hline $\begin{array}{l}\text { 10. Hanson } \\
\text { and Sigman }\end{array}$ & $\begin{array}{l}\text { They identified three capacity factors: administrative, fiscal } \\
\text { (extractive function) and coercive potential. }\end{array}$ & $\begin{array}{l}\text { Leviathan's latent dimensions: measuring State } \\
\text { capacity for comparative political research, } 2013 .\end{array}$ \\
\hline
\end{tabular}

Source: Elaborated by the author. 
As shown in Box 1, the literature has a wide variety in the elaboration, decomposition and operationalization of the IC concepts. While some researchers focus on the diagnosis of Brazilian states IC in social assistance (Silva, 2015), others hold a more comprehensive perception of the IC, taking into account the degrees of competence and the levels of resources used for the production of public policies, which are subdivided into twelve IC analysis dimensions (Howlett, 2015).

Therefore, according to Cingolani (2013), there are different approaches to the measurement of IC. The approaches that involve the creation of indicators (uni or multidimensional) are the most common strategy for the study of IC.

Supporting Cingolani (2013), Gomes (2010) states that there are many empirical approaches related to IC. In the Brazilian case, the focus is generally on the relationship of the three government spheres, due to the fact that the federative environment is conducive to the discussion of the IC, since its entities compete in the capacities of the state. Among the many, three main approaches should be examined.

The first approach concentrates on fiscal decentralization as a sufficient and necessary dimension to explain the increase in government IC. Specifically, it supports the view that the freedom to tax and allocate resources by subnational governments is the key to increasing their IC. Hinged on the concepts of market balance, the theorists of this perspective suggest that local governments know better the preferences and needs of their citizens in relation to the central government. According to Oates (1999), the expectation is that this level of government would be able to obtain information at a lower cost, in addition to being more efficiently capable of proposing and implementing public policies related to perceived needs.

In this way, a "healthy competition for customers" would occur and, in turn, prompt local governments to provide the best baskets of public products/services at the lowest tax rates. In Oates (1999)'s words:

It turns out that it is straightforward to develop an analogue to perfect competition in the private sector. In such a setting, governments compete with one another for a mobile capital stock that both generates income for local residentes and provides a tax base for them-and such competition leads local officials to adopt efficient levels of outputs of public goods and tax rates. In these models, the invisible hand works in much the same way as in the private sector to channel policy decisions in individual jurisdictions into an efficient outcome from a national perspective (Oates, 1999, p. 1135).

However, it should be noted that, in this interpretative model, political, structural and institutional elements are disregarded, such as: a) the motivation of politicians; b) the role of local bureaucracies; c) the performance of stakeholders in decisionmaking processes; d) the organizational structure; e) human capital, etc. This aspect limits the role of central governments in creating policies that need national coordination, as is the case of intergovernmental transfers and macroeconomic policies.

The second approach understands subnational governments not as autonomous entities, but as entities inserted in a context of government regulation. Therefore, this line of analysis represents an advance in the sense of considering the administrative, fiscal and political aspects of decentralization, along with their respective impacts on government's IC. This explanatory strand proposes a break with the simplified notion that there is one condition alone that is sufficient for the autonomy and the increase of subnational governments' capacity.

The main criticism of this group of analyses is in relation to the operationalization of the measures that should reflect analytical concepts on the one hand, and the difficulties inherent in comparative studies on the other, especially when the distinction between degrees and forms of decentralization renders the analyses more complexity. The variation in the ways of classifying degrees and types of decentralization also ends up producing discrepant results (Gomes, 2010, p. 115).

However, as exposed by Gomes (2010) in the excerpt, the main criticism from theorists raised against this strand relates to the lack of uniformity of the operationalization and measurement of information regarding the decentralization levels and the IC. It is then necessary to create a common conceptual framework for further empirical research.

The third conception refers to the effectiveness of the decentralization process in the institutional design of reforms. Thus, the adoption of specific institutional projects would increase the IC of administrative structures, for example, by increasing: a) accountability; b) tax liability mechanisms; c) the institutionalization of social participation channels; d) the guarantee of fiscal and administrative capacities for the provision of services, etc. 
Nevertheless, Litvack, Ahmad and Bird $(1998$, p. 2) emphasize that the fiscal and administrative capacity of local governments should precede the adoption of these institutional projects and, for this reason, several developing countries' governments often do not respond to their citizens, because "decision-making is rarely transparent or predictable. The opportunities to supervise and the results are both limited because of weak institutions". In this sense, institutions are considered weak when they do not have IC to provide services to the social group.

The elements presented enable the association between the process of decentralization reforms and the IC of subnational entities. It appears that institutional rules can cause effects that vary according to the context in which they are adopted, since the actions of the central government are considered to limit the autonomy of choice of the "policy package" and, as a result, interfere in the performance of subnational governments.

It is important to stress the existence of inquiries that follow the three explanatory approaches, among which the following stand out: a) theoretical mimicry, coming from contexts other than the Brazilian one; b) the variability of service provision, as a mechanism for inequalities; and c) the specificities inherent to each territory, since each locality would have different capacities (fiscal, administrative, etc.) to respond to their citizens' "preferences".

\section{The relevance of a scoping review on institutional capacity}

The increasing use of research methods called "scoping review" or "integrative review" of literature evidences the need to order all the literature on a specific topic produced by one or more fields of knowledge. In this sense, although there is no universally accepted definition of scoping reviews, it is agreed that the most striking feature of this method is the possibility of an overview on an admittedly broad topic (Peterson, Pearce, Ferguson \& Langford, 2017).

Therefore, the process of mapping and structuring information provided by the scoping literature review aims to demonstrate the current state of the art and to elucidate the existence of gaps, or opportunities, of knowledge on a given topic, contributing to further scientific investigations.

Furthermore, Ramos, Faria and Faria (2014) note that, due to the growing number of individuals who benefit from a wide range of resources available in the virtual environment, selecting and appraising what is or is not scientifically relevant becomes more and more complex. For this reason, the scoping literature review serves as a facilitator, as an important knowledge aggregating tool, which helps to achieve the purpose of this study: the understanding of the theoretical-conceptual structure of the IC theme in the national academy.

This literature review was grounded on the evidence provided by the existing studies in the international literature on IC, which highlighted, on the one hand, the need to create a conceptual structure that allows the understanding of the IC concept and, on the other, exposed the subjective nature of the IC representative variables, a characteristic that hinders the creation of a consensual definition that encompasses the whole theory involving this theme (Addison, 2009; DeRouen et. al., 2010; Lessik \& Michener, 2000; Wu, Ramesh \& Howlett, 2015).

Consequently, the theoretical mapping of IC in the national context is relevant, since it aims to provide the scientific field of public administration with important theoretical subsidies. This mapping is described through the operationalization of the scoping literature review in the next section.

\section{METHODOLOGY}

This research is a descriptive work with a mixed approach, qualitative and quantitative, because it proposes to describe the IC phenomenon through the examination of studies carried out on this theme in academia. For that, statistical tests were used to quantify all the verbal material collected and extract its units of meaning (Camargo \& Justo, 2013).

According to Rumrill, Fitzgerald and Merchant (2010) and to Silva, Fonseca, Mafra and Freitas (2016), the scoping or integrative review process is a preliminary form of investigation that seeks to identify, evaluate and interpret all relevant research on a given topic, providing a synthesis of the knowledge produced and offering subsidies for the scientific field, aiding the development 
of questions and proposals for further research. To this end, this integrative review was operationalized with the support of IRAMUTEQ, Pajek and MAXQDA software programs.

IRAMUTEQ is a free software that enables statistical analysis of transcribed verbal material. It assists the lexicographic analysis of a given word corpus and translates the essence of selected texts through descending hierarchical classification (DHC), which enables the description, classification and interpretation of words based on the content analysis guidelines (Camargo \& Justo, 2013; Ratinaud \& Marchand, 2012).

Pajek is also a free software and its purpose is to analyze and visualize networks. Its most important contributions refer to the possibility of analyzing large social networks and to the use of algorithms that facilitate a graphic representation of data matrices, in order to help the interpretation of social networks in an integrated way (Molina, Muños \& Doménech, 2002).

The word tree tool, available in the MAXQDA software, allows the researcher to analyze how certain words, or locutions, are used in phrases or speeches in a textual corpus. Thus, the word tree provides a visualization of the connections identified between the keyword (institutional capacity) and the entire selected textual corpus, through a system of branches (Wattenberg \& Viégas, 2008).

To elucidate the current state of the art and advance empirically in studies on IC, it was necessary to comprehend the articles that make up the IC theme. Therefore, the use of tools that assist the integrative review process is justified, as it allows the researcher to explore data and information in a broader scope (Levy \& Ellis, 2006). Besides these aspects, it is important to emphasize that the software programs do not impose a methodological approach, on the contrary, they are complementary tools. Thus, it is up to the researcher to select and apply the different strategies that will guide their study(studies) (Saillard, 2011).

\section{Operationalization}

The procedures adopted in this scoping literature review followed the guidelines suggested by Ramos et al. (2014) (Box 2).

Box 2

Scope review operationalization

\begin{tabular}{|c|c|}
\hline Goals & $\begin{array}{l}\text { Investigate the scientific production, the state of the art of the Brazilian academy on the subject of } \\
\text { institutional capacity (IC), synthesize information, contribute to the formulation of questions and } \\
\text { proposals for further research and empirically advance in the studies on IC. }\end{array}$ \\
\hline & “Institutional Capacity”. \\
\hline & All databases belonging to the CAPES Journal Portal within the scope of public administration. \\
\hline & $\begin{array}{l}\text { Only published articles that fit the proposed verification theme (IC) with a Qualis Capes equal to or greater than } \\
\text { B2 and within the timeframe defined for the review will be selected, that is, articles published between January } \\
\text { of } 2008 \text { and March of } 2018 \text {. }\end{array}$ \\
\hline & $\begin{array}{l}\text { Articles that are not in the pre-defined Qualis Capes, articles prior to the defined time frame, articles outside } \\
\text { the scope of public administration and articles that have no abstract and are not written in Portuguese. }\end{array}$ \\
\hline & Descending hierarchical classification (DHC), network analysis and textual analysis. \\
\hline & $\begin{array}{l}\text { Record of the steps, analyze and critically describe the results with the help of the software programs: } \\
\text { IRAMUTEQ, Pajek and MAXQDA. }\end{array}$ \\
\hline
\end{tabular}

Source: Elaborated by the author. 
The model proposed by Ramos et al. (2014) reinforces the need to carry out an integrative review in seven stages. From this perspective, this work incorporates the planning, the execution and the analysis of results.

\section{Record of the steps}

The stage of collection articles on IC was carried out between January 2018 and March 2018. In this interval, 102 articles with potential for analysis were examined, and, out of them, 31 were selected and had their data extracted and analyzed, according to the recommendations provided for in the operationalization protocol (Appendix - Box A).

The criteria for selecting articles for the scoping literature review was processed in three steps. First, the keyword institutional capacity was included in the advanced research field of CAPES Journal Portal. After that, all articles transcribed in Portuguese that had an abstract were selected, following the inclusion criteria. In the next phase, after having read the abstracts and introductions of the selected articles, those that had a theme consistent with the public administration scope were included. In the last stage, after a thorough reading of all selected articles, the textual corpus was prepared for further analysis with the software programs applied in this study.

The search source (indexer) CAPES Journal Portal was chosen due to several factors, among which the following stand out: a) the ease of access to scientific information via the internet; b) the possibility of access to updated knowledge; and c) the inclusion of the main journals (bases) within the scope of public administration in its online collection.

The option for the strata comprising Qualis Capes B2 to A1 was due to the fact that they are considered the most relevant in terms of the intellectual production quality of graduate programs in Brazil (Coordenação de Aperfeiçoamento de Pessoal de Nível Superior [CAPES], 2018). Furthermore, Pedroso and Pilatti (2009) observe that the works included in strata B2, B1, $A 2$ and A1, according to the CAPES Periodical Classification for Public Administration in the 2013-2016 Quadrennium, can be considered a proxy of relevance and scope.

The criteria for inclusion of articles written only in the Portuguese language was related, at first, to the proposal for the evaluation of national scientific production on the IC theme and, secondly, to the inability of software programs to analyze the same textual corpus with different languages.

\section{Operationalization of the descending hierarchical classification}

In order to explore and analyze the data, all the material included was analyzed in the software IRAMUTEQ, version 0.7, alpha 2. In this process, the selected textual segments were linked to a single file, called "Corpus Textual" (Textual Corpus). Each article was identified by a command line that defined the characteristics that would constitute the "textual statistical analysis" scope. It is worth mentioning that the textual corpus processed in the IRAMUTEQ software was composed of abstracts and introductions of all articles that met the specifications of the literature review. It is also important to emphasize the need for changes in the textual corpus for the optimization of the software analysis, based on the classic lexical analysis.

In accordance with the studies by Azevedo and Miranda (2012) and Silva et al. (2016), the following analysis methods were used:

A) Classic lexical analysis: these interfaces perform the word stemming process. They classify the reduced forms of some words, such as: creation, creative, creationism, which will be classified as "create". However, each word is classified according to its grammatical type. After this stage, the frequency analysis and the chi-square test $\left(\mathrm{chi}^{2}\right)$ of each word of the textual corpus with its respective reduced form was conducted. In this way, it was possible to verify the probability of an association between the forms/words and the variables operated or the textual corpus.

B) Reinert's hierarchical classification method (DHC): this method makes it possible to count words by the frequency of co-occurrence, based on grammatical classes loaded with cognitive meanings that can be examined. Therefore, calculations are made from the co-occurrence of words in text segments, in order to distinguish the classes of words that represent different forms of discourse on the topic of investigation. Thus, based on the "descending hierarchical classification", the classes are represented in comparison with their degree of occurrence and similarity.

Both in the classic lexical analysis and in the Reinert method (DHC), only the textual segments whose chi-square scores were equal to 3.84 ( $p \leq 0.05$ ) were considered, that is, the significant values. 


\section{Network analysis operationalization}

International studies on social networks can be analyzed in four distinct phases. The phase that designates the current context is characterized by a greater ease of access to information (internet) and evolution of computational tools, such as network analysis programs and software programs (Zampier, 2007). According to Lopes (1997), there are important literature reviews on network theory and analysis, and the study by Stanley Wasserman and Katherine Faust (1994) presents an in-depth review of social network analysis methodologies and their applications.

In order to verify which researchers are a reference in studies on IC and to elucidate the existence of connections between the theoretical frameworks of all articles, a network analysis of the articles selected for the scoping review and its respective bibliographic references was conducted. Thus, the analysis of citations expressed a relationship between 2 pairs: a) the author of the cited text; and b) the author of the citing text. As the scientific texts are cited, they create an interweaving of relationships that helps to understand the state of the art of a given theme, consolidating the analysis of the network of authors (Romancini, 2010).

For the network elaboration, the articles selected were characterized as nodes and, to establish the interconnection among them, the citations of these articles were considered. Therefore, the gray dots (nodes) correspond to the 31 articles selected for the scoping review. The red dots (nodes) are the referenced articles, each quote will be characterized with an arrow (arcs) (Figure 3). The centrality of the network is defined by the number of existing relationships between an actor (node) and other actors. This means that the most central actors are those that have the greatest amount of relationships with other authors who have studied the IC concept and, theref ore, develop a more important role within the network (Wasserman \& Faust, 1994).

The most common denominations in network analysis were synthesized with the intent of facilitating the understanding of the study (Box 3). The characteristics of the groups, the density and the centrality of the authors are analyzed through the creation of networks. It is important to note that the Fruchterman-Reingold (2-D) algorithm of the Pajek software, version 645.05 , facilitated this process, as it allowed the visualization of the networks of authors and their interpretation.

\section{Box 3}

\section{Data structures in Pajek software}

\begin{tabular}{|c|c|}
\hline Nodes & $\begin{array}{l}\text { They are the people or groups of people that group together with a common goal. The nodes } \\
\text { are represented by circles. The sum of all nodes indicates the size of the network. }\end{array}$ \\
\hline Arcs/streams & $\begin{array}{l}\text { These are the lines that represent the connection between two vertices, however, they have } \\
\text { directional signs. }\end{array}$ \\
\hline Density & $\begin{array}{l}\text { The density of the network demonstrates the connectivity of the actors that comprise the } \\
\text { network. That is, it elucidates the number of existing relationships in face of the number of } \\
\text { possible relationships. }\end{array}$ \\
\hline Centrality & The degree of centrality consists of the number of nodes with which a node is directly related. \\
\hline Outdegree & The degree of output is the sum of the interactions that the actors (nodes) have with others. \\
\hline
\end{tabular}

Source: Elaborated by the author.

\section{Interactive word tree operationalization}

According to Gibbs (2009) and Evers (2011), qualitative data analysis software programs are characterized as tools that optimize the qualitative analysis of texts. Therefore, the use of software programs changes the way researchers treat qualitative data, since it facilitates the visualization of the relationships among data sets and enables the coding, categorization and association of the classes present in the analyzed texts. In addition, it allows the replication of all processes, making them not only more agile, but also more transparent.

The operationalization of the word tree tool, available in MAXQDA software, version 12.3.2, started with the insertion of the keyword institutional capacity in the search box. After this process, the keyword was mapped in all articles selected for the scoping review, which were also inserted in the software database. Thus, the various words and semantic contexts subsequent 
to the keyword defined the ramifications of the word tree. Therefore, the use of this tool allows both the visualization of the context in which the terminology institutional capacity fits and the examination of any conceptual divergences observed in the 31 articles selected for the scoping review (Henderson \& Segal, 2013).

Therefore, the use of the word tree assists complementing the analysis of the results, by identifying patterns of meaning and the spatial organization of the terminology studied in the articles selected for the scoping review.

\section{RESULTS AND DISCUSSION}

\section{Data description}

The data description stage observed the following criteria: a) publication year; b) publication's relevance (Qualis Capes); and c) study design (methodological approach).

By examining the year of the publications, both the incipience of academic studies and the gradual increase in the number of publications on the IC theme were identified, since most of the articles' publications were concentrated in the period from 2014 to 2016 (Figure 1). The relative absence of publications in the years 2017 and 2018 may be related to the period of evaluation of the articles.

Figure 1

Number of publications on institutional capacity from 2008 to 2018

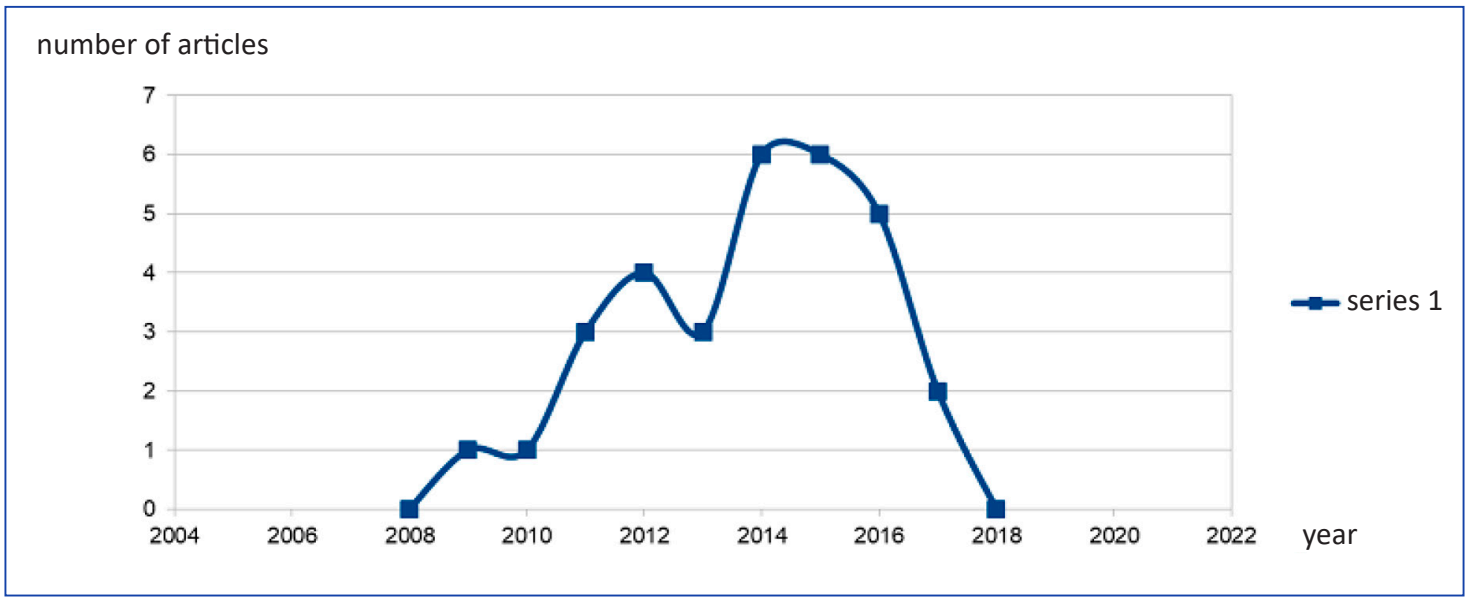

Source: Elaborated by the author.

The analysis of the relevance and of the scope of publications revealed that the absence of articles on IC in journals that are part of the "Qualis-CAPES" platform A1 strata may reflect this research's methodological option, which included only articles written in the Portuguese language in the scoping review. However, the predominance of publications in the A2 strata (55\% of articles) indicates that the IC theme has relevance in the academic field in the national context.

Another relevant information was obtained from the analysis of IC research delineation: there is a multiplicity of methodological approaches such as, theoretical essays and studies that explore the use of both the qualitative and quantitative approaches in research on IC (Table 1$)$. 
Table 1

Analysis of institutional capacity studies approaches

\begin{tabular}{|c|c|c|c|c|c|}
\hline Methodological Approach & Frequency & \multicolumn{4}{|c|}{ Qualis Capes Stratum (Percentage) } \\
\hline Theoretical Essay & 1 & \multicolumn{4}{|c|}{ B2 (100\%) } \\
\hline Quantitative & 15 & \multicolumn{4}{|c|}{ A2 (56,3\%); B1 (40\%); B2 (20\%) } \\
\hline Qualitative & 9 & \multicolumn{4}{|c|}{ A2 (25\%); B1 (30\%); B2 (60\%) } \\
\hline Mixed approach & 6 & \multicolumn{4}{|c|}{ A2 (18,8\%); B1 (30\%) } \\
\hline Total & 31 & $\begin{array}{c}\text { T. Essay } \\
3,2 \%\end{array}$ & $\begin{array}{c}\text { Qualitative } \\
32,3 \%\end{array}$ & $\begin{array}{c}\text { Quantitative } \\
45,2 \%\end{array}$ & $\begin{array}{l}\text { Mixed } \\
19,4 \%\end{array}$ \\
\hline
\end{tabular}

Source: Elaborated by the author.

Additionally, the chi square test $\left(\mathrm{chi}^{2}\right)$ was performed to examine the degree of association between the "Qualis Capes" of the journals and the adopted methodological design. Therefore, it is not possible to reject the hypothesis (HO), which asserts that there is an association between the "Qualis Capes" of the journals and the research design.

Given this context, it can be considered that the IC theme in the national literature is recent, comprehensive, has great potential for publication in different research areas and includes different methodological approaches. However, studies focusing on IC still lack consensus. Such aspect is verified from the theoretical plurality of the references that were analyzed and is later discussed.

\section{Descending hierarchical classification}

The first phase of the lexical analysis evidenced the information related to the visualization of the more general textual corpus data, which was formed by 31 units of initial contexts (UICS). When using the chi-square test, the 31 UICs were broken down into 4,498 elementary context units (ECUs), which totaled 25,221 textual occurrences analyzed. In that number of occurrences, there were 3,188 distinct words. Through the standardization of the vocabulary in its primitive form, 2,066 occurrences of words were analyzed.

According to Nascimento and Menandro (2006) and Azevedo and Miranda (2012), the grouping of semantic roots and the definition of classes considers the word function in each text. Therefore, it is possible to both quantify and infer about the class delimitation, since the DHC method counts words by pondering: occurrence, co-occurrence and the words' textual function in the textual corpus, distinguishing the classes that represent distinct discourse forms upon the topic of interest to the investigation.

Thus, based on the "descending hierarchical classification" (DHC), the classes are represented in comparison with their degree of occurrence and similarity so as to enable: the description, classification and interpretation of the text segments. The dendrogram (Figure 2) structured the subdivision of the classes that make up this research's textual corpus. 
Figure 2

Descending hierarchical classification

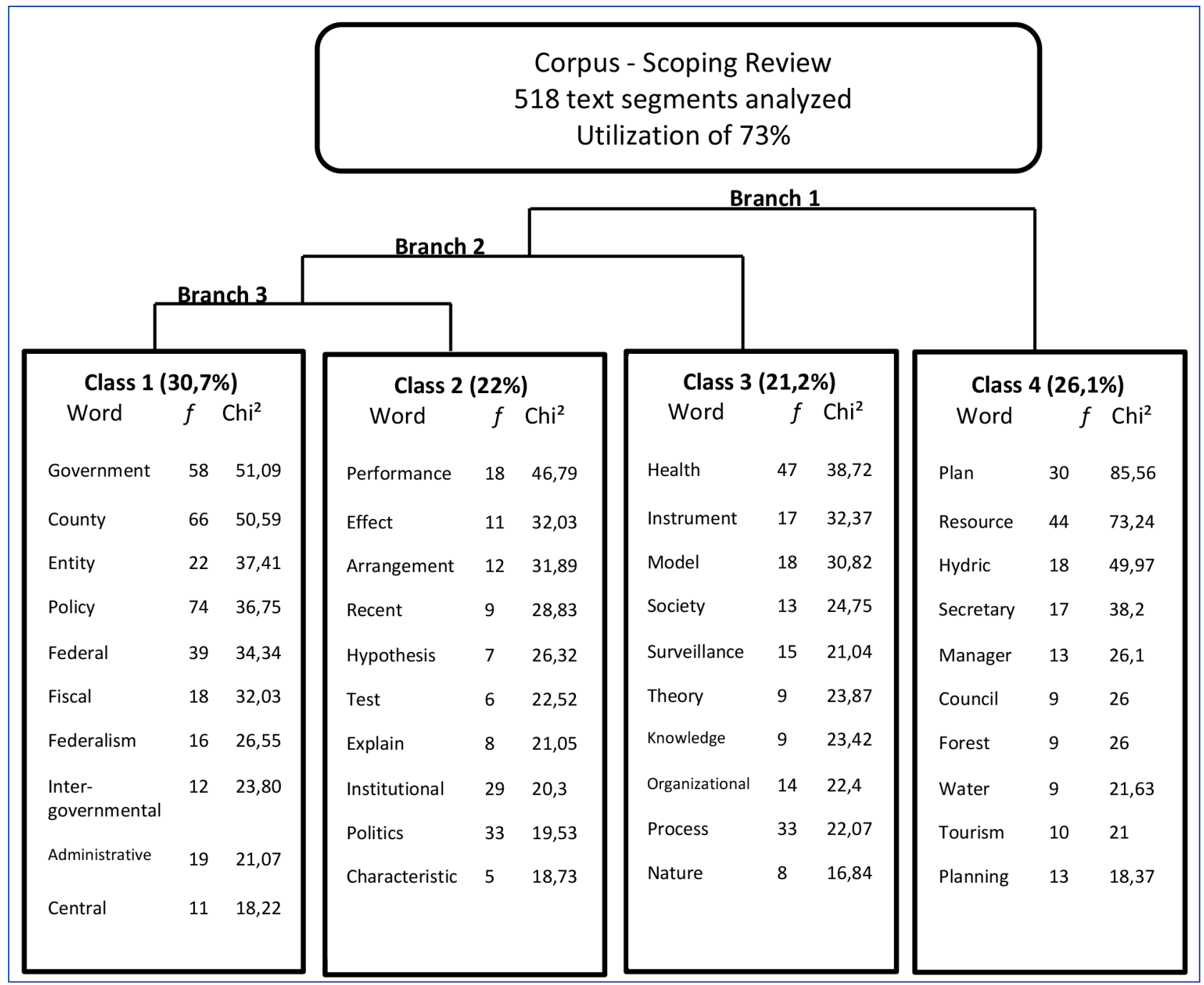

Source: Elaborated by the author.

As seen in Figure 2, the textual corpus was divided into 4 classes, which were subdivided into 3 branches. For a better visualization of each class characteristics, the 10 most expressive words were listed according to: a) their frequency (f); and b) their degree of association $\left(\mathrm{chi}^{2}\right)$ with the corresponding class.

However, before starting the discussions on the results from the DHC method, it is important to clarify that the percentage of retention and use of the analyzed texts was higher than that specified by the current literature (Camargo \& Justo, 2013; Ratinaud \& Merchand, 2012). Therefore, 73\% of the text segments were used, which was equivalent to 518 text segments that were present in the 31 articles selected for the scoping review.

Class 1, considered the one with the greatest explanatory power, involved $158 \mathrm{ECUs}$, representing $30.7 \%$ of the entire textual corpus. Class 4 was made up of 135 ECUs, which corresponded to $26.1 \%$ of the textual corpus. In turn, classes 2 and 3 represented, respectively, $21.2 \%$ and $22 \%$ of the corpus. Accordingly, it was observed that the third branch, composed of classes 1 and 3, explains the analyzed content better, which means that the third branch - which has an explanatory power equivalent to $51.9 \%$ of the entire textual corpus - is considered the most relevant in understanding the articles related to the IC theme. 
Based on all the available information, it appears that class 4, named "Theoretical Reference", translates into the basic structure of the entire textual corpus in the analyzed articles. Thus, class 4 comprises the most general theories, related to the other classes (2, 1 and 3). When analyzing the word network formed in class 4, it is possible to identify the lexical content grouped together, mainly around the words: plan and resource. Situation explained by the following passages, extracted from class 4 UICs:

[...] the plan for strengthen tourism management, the natural and cultural heritage of municipalities $[\ldots]$ is also committed to ensuring that municipalities have the autonomy to identify and to seek other financing channels made available by the federal government [...] (Araújo \& Possenato, 2012, p. 223, own translation) (UIC 28).

[...] Another relevant observation cited by the authors concerns the difficulty in achieving positive results through environmental policy, as environmental reflection is incipient in many countries and, for this reason, industrialization and the constitution of life in society are different from the environmental preservation model. These facts represent obstacles to the effective reduction of pollution levels. Among the most recurrent problems tangential to its implementation and inspection, it is relevant to mention: the lack of monetary resources, the low institutional capacity and the insufficiency of human resources [...] (Neitzk, Gonçalves, Oliveira, Machado \& Gibbon, 2015, p. 75, own translation) (UIC 14).

The conclusion is that the representative class 4 text segments constituted elements related to the research of each article, whether within the scope of: a) administrative planning; b) societal planning; c) federal management; or d) the subnational levels of government (states and municipalities). It is also important to note that the IC theme appears, generically, in the government plans and IC strengthening plans. In short, from class 4 derives the remaining branches that will form the other classes.

Class 2, named "Discussions" and which belongs to the second branch, has a stronger relationship with class 4, which indicates its dependence, since it explains the questions proposed by the first branch. Thus, despite the lower retention percentage of textual segments, the word grouping health, society, health surveillance and nature (environmental management) highlights each research locus, while the text segments instrument, model, theory and knowledge relate to the theoretical foundation and methodological operationalization employed by each article. The excerpts selected from the UICs evince this aspect:

[...] These theories dealt with theoretical concepts such as corporate culture, organizational productivity, communications and models and management practices, among others. The concept of institutional capacity has shown its limitations in focusing the object of study in organizations on purely technical aspects [...] (Vidal, 2014, p. 668, own translation) (UIC 4).

[...] The monitoring instrument was built after outlining the logical health surveillance management model and the representative indicators of each management component underwent a validation process. In addition to supporting decision making, monitoring is understood as a reflective practice capable of promoting personal and institutional learning, continuous management processes improvement, greater transparency and accountability [...] (Costa, Felisberto, Bezerra, Cesse \& Samico, 2013, p. 1201, own translation) (UIC 24).

The third branch is considered to have the greatest explanatory power because, together, classes 1 and 3 correspond to approximately $52 \%$ of the analyzed textual corpus.

As shown in Figure 3, the third branch is subdivided into 2 sub-corpuses (classes 1 and 3), which, despite having differences in their structure, have a common content: the object of analysis, that is, the IC. Such subdivision exposes, on the one hand, class 1 - which relates to the theoretical foundation derived from the dimensions of IC analysis - and, on the other hand, class 3 - which demonstrates the causal relationship between the research hypotheses and the IC examination.

Class 3, entitled "Results", indicates the research hypotheses and specificities inherent to the results and effects attributed to the increase or decrease in IC. It is important to observe that in this class the IC concept remains broad, relating to each research scope, which means that there is no precise definition of what it is or are the indispensable conditions for the IC existence or increase. Class 3 most representative textual segments are: performance and effect. The following selected UIC excerpts support the proposed interpretation: 
[...] the results, in turn, suggest that institutional capacities have a positive effect on economic development. In short, the greater the country's institutional capacity, the greater its economic performance [...] (Silva, Cunha, Domingos \& Torres, 2015, p. 332, own translation) (UIC 20).

[...] it proposes to analyze the determinants of Brazilian city halls' performance, from the perspective of government efficiency. The main objective is to analyze the effects of electoral competition on the efficiency of local governments in the implementation of social policies [...] (Cavalcante, 2013, p. 1570, own translation) (UIC 3).

The examination of class 1, named "Dimensions of Institutional Capacity", elucidated an exceptional situation, in which the words government, municipality, entity, federal, federalism and central signaled the different levels of government influencing and influenced by IC:

[...] Federative political systems are characterized by the existence of territorial distribution of political authority, which means that, in the same territory within the same State, more than one government may be responsible for the exercise of political power. Therefore, the federated entities have autonomy - which can vary among the different models of existing federative systems [...] (Pallotti \& Costa, 2011, p. 211, own translation) (UIC 30).

The word grouping political, fiscal and administrative, however, indicated the IC analysis dimensions.

[...] In the case of government programs implemented with the purpose of strengthening the institutional capacity of federal entities and sectors of public administration, there seems to be a close link between institutional capacity and capacity for planning and managing public policies through administrative processes rationalization, modernization of information systems, the establishment of relations with actors of cooperation and collaboration [...] (Fernandes, 2016, p. 703, own translation) (UIC 10).

[...] fiscal, administrative and political indicators are used to measure the institutional capacity of the 26 state governments and the Federal District in social assistance. This will serve to verify whether the creation of national public policy systems contributes to the institutional strengthening of the government spheres, in this work, in state governments [...] (Silva, 2015, p. 1169, own translation) (UIC 11).

It was noted thereby that the theoretical expectation present in class 1, related to the IC dimensions, meets the theoretical expectation of renowned IC researchers, such as Huerta (2008), Gomes (2010), Cingolani (2013) and Wu et al. (2015), who point out that one of the greatest challenges for studies on IC is the "performance measurement" and that most of these studies are characterized by a confusion between means and ends in an attempt to measure the IC. In this sense, it is possible to infer that in order to empirically advance, a study on IC cannot do without the dimensions highlighted by class 1 , that is, the administrative, political and fiscal dimensions.

\section{Network analysis}

The main reason to use the network analysis technique was to understand the state of the art of Brazilian studies on IC, through citation networks of the articles selected for the integrative review. According to Soares (1989, p. 3), an understanding of a field's state of the art is necessary for its evolution, so that it allows "the indication of integration possibilities from different perspectives (apparently autonomous), the identification of duplications or contradictions, and the determination of gaps and biases". In a complementary way, the network analysis also aimed to examine the existence of a reference researcher in studies on IC.

The analysis of citations networks is thereby crucial to indicate the sources of information that most influence the national literature on the IC theme. Therefore, the network was created from gray nodes (representing the 31 articles selected for the scoping review), red nodes (representing the 31 articles' bibliographies) and arcs (representing the citations between the nodes). 
Having these parameters in mind, it was observed that the IC authors network has a very low density (0.14\%), indicating that the network is sparse and has little cohesion, which is the opposite of the ideal situation, since it had the presence of dense and widely integrated authors networks. This implies the existence of articles that, despite addressing the IC theme, do not even have a common bibliographic reference, they are "theoretical islands", and the articles selected for the review do not dialogue directly with each other (Figure 3). There was also no identification of a Brazilian author with a high number of publications among the 31 articles selected for the integrative review; the authors Fabiana Silva Fernandes and Eduardo José Grin stood out, with 2 publications each.

Therefore, the non-consolidation of the state of the art of the IC theme is verified by the lack of dialogue and the low density of relationships among the articles selected for the integrative review; by the centrality of the Federal Constitution (FC) of 1988 as the most cited theoretical reference in the 31 selected articles; and by the existence of "theoretical islands", that is, articles that present their own IC study structure (Figure 3).

Figure 3

Authors' network analysis

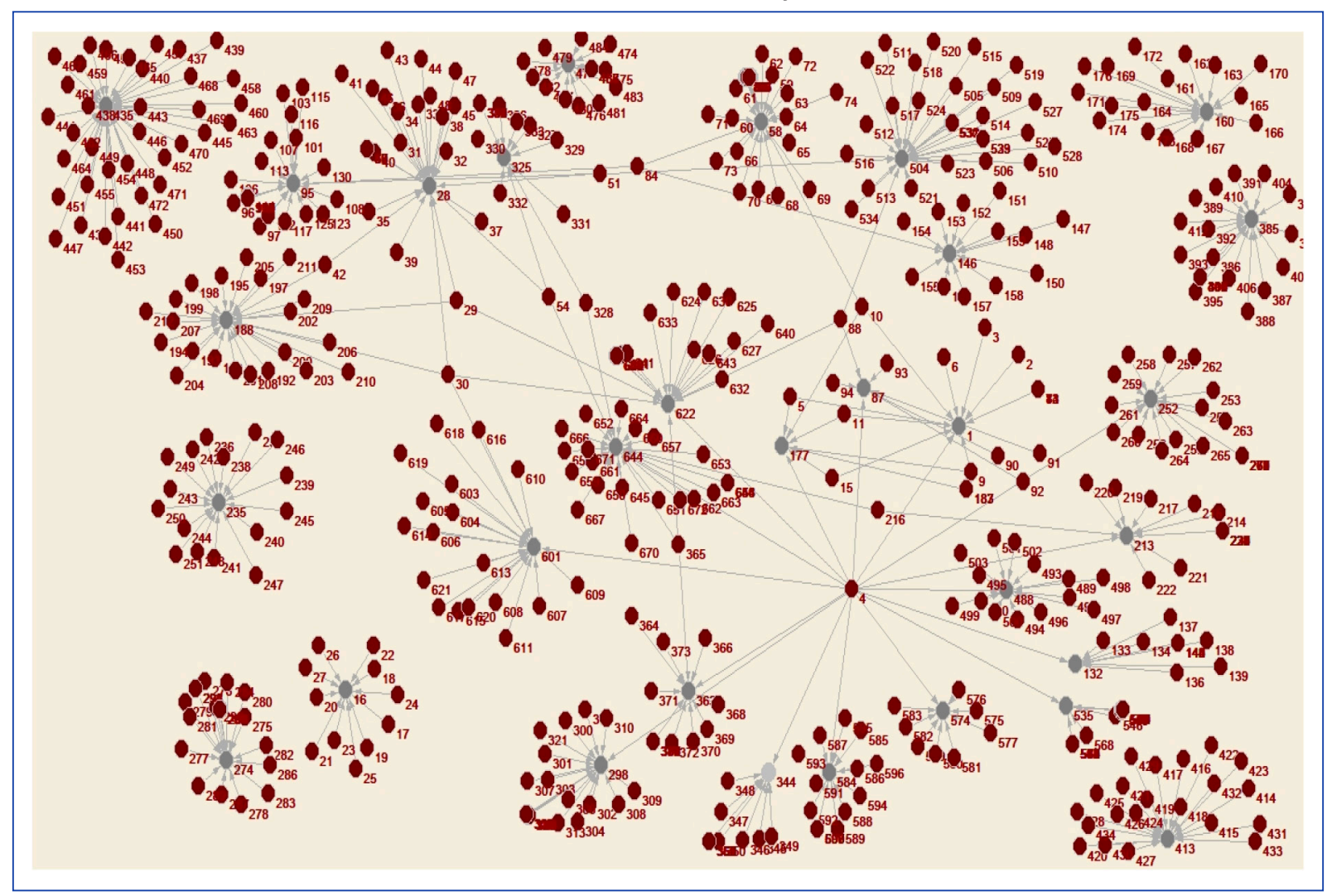

Source: Elaborated by the author.

The centrality of the authors network is defined by the number of existing relationships between an actor (node) and other actors. This means that the most central actors are those that have the greatest amount of relationships with other actors and, therefore, assume a more important role within a given network (Wasserman \& Faust, 1994).

In this analysis, the Federal Constitution of 1988 stands out, with a degree of centrality "outdegree/output degree" equal to 17, meaning that it is characterized as the main reference for the authors who studied the IC, having been cited in 17 of the 31 articles selected for the integrative review.

In order to facilitate the understanding of the authors' networks structure on IC, Table 2 presents the cited bibliographies (red nodes) labels with greater centrality in the authors' network. In this way, it is possible to visualize the presence of at least three analysis groups. 
The first group is characterized by laws, decrees and norms from the $1988 \mathrm{FC}$, which are specific to each context of research on IC. This characteristic stresses the network's low density and the non-consolidation of the state of the art on IC, since such laws, decrees and norms restrict the IC concept, subdividing it into specific functions to the detriment of a more general approach. The second group relates to authors who research the context of Brazilian federalism, such as Marta Arretche and Celina Souza, confirming the need for studies on IC to contextualize the institutional framework of the studied governments (Lindvall \& Teorel, 2016). The third group, in turn, mentions articles referring specifically to the IC concept, namely: Cruz et al. (2011), Lessik and Michener (2000), Lubambo and Coutinho (2004) and Mizhari (2004), which establish guidelines and theoretical foundations for this concept measurement and analysis.

Table 2

Network labels

\begin{tabular}{|c|c|c|c|}
\hline $\begin{array}{l}\text { Bibliography } \\
\text { code }\end{array}$ & Bibliography & Year & $\begin{array}{l}\text { Number of citations } \\
\text { (outdegree centrality) }\end{array}$ \\
\hline 4 & $\begin{array}{l}\text { Constituição da República Federativa do Brasil de 1988. (1988). Brasília, DF: } \\
\text { Presidência da República. }\end{array}$ & 1988 & 17 \\
\hline 30 & $\begin{array}{l}\text { Arretche, M., \& Marques, E. (2002). Municipalização da saúde no Brasil: diferenças } \\
\text { regionais, poder do voto e estratégias de governo. Ciência \& Saúde Coletiva, 7(3), } \\
\text { 455-479. }\end{array}$ & 2002 & 4 \\
\hline 5 & $\begin{array}{l}\text { Cruz, M. C. M. T., Montoro, F. A. F., Bio, S. R., Viana, M. T., Craveiro, S. S., \& Castro, } \\
\text { T. P. (2011). Gestão pública no Estado de São Paulo: elementos para um olhar } \\
\text { analítico. In J. F. A. Veloso, L. M. Monasterio, R. S. Vieira, \& R. B. Miranda (Orgs.), } \\
\text { Gestão municipal no Brasil: um retrato das prefeituras (pp. 87-140). Brasília, } \\
\text { DF: Instituto de Pesquisa Econômica Aplicada. }\end{array}$ & 2011 & 3 \\
\hline 9 & $\begin{array}{l}\text { Lessik, A., \& Michener, V. (2000). Measuring institutional capacity (Recent Practices in } \\
\text { Monitoring and Evaluation Tips, n. 15). Washington, DC: International Development } \\
\text { Cooperation Agency/United States Agency for International Development. }\end{array}$ & 2000 & 3 \\
\hline 29 & $\begin{array}{l}\text { Arretche, M. (2004). Federalismo e políticas sociais no Brasil: problemas de } \\
\text { coordenação e autonomia. São Paulo em Perspectiva, 18(2), 17-26. }\end{array}$ & 2004 & 3 \\
\hline 10 & $\begin{array}{l}\text { Lubambo, C. W. (2002). Conselhos gestores e desempenho da gestão nos municípios: } \\
\text { potencialidades e limites (Textos para Discussão, n. 149). Recife, PE: Fundação } \\
\text { Joaquim Nabuco. }\end{array}$ & 2002 & 3 \\
\hline 54 & $\begin{array}{l}\text { Souza, C. (2005). Federalismo, desenho contitucional e instituições federativas no } \\
\text { Brasil pós-1988. Revista de Sociologia e Política, 24, 105-121. }\end{array}$ & 2005 & 3 \\
\hline 88 & $\begin{array}{l}\text { Arretche, M. (1999). Estado federativo e políticas sociais: determinantes da } \\
\text { descentralização. Revista Brasileira de Ciências Sociais, 14(40), 111-141. }\end{array}$ & 1999 & 3 \\
\hline 633 & $\begin{array}{l}\text { Evans, P. B., Rueschmeyer, D., \& Skocpol, T. (2002). On the road toward a more } \\
\text { understanding of the state. In P. B. Evans, D. Rueschmeyer, \& T. Skocpol (Eds.), } \\
\text { Bringing the State Back In (pp. 347-366). Cambridge, UK: Cambridge University Press. }\end{array}$ & 2002 & 2 \\
\hline 11 & $\begin{array}{l}\text { Mizrahi, Y. (2004). Capacity enhancement indicator: review of the literature. } \\
\text { Washington, DC: World Bank Institute. }\end{array}$ & 2004 & 2 \\
\hline
\end{tabular}

Source: Elaborated by the author.

Therefore, this study highlighted the lack of dialogue among national authors who address the IC theme. The existence of gaps was also evidenced, indicating conceptual inconsistencies, due to the non-consolidation of the IC state of the art at the national level. These aspects evidence the need for revisions in order to map the state of the art and debate the different perspectives surrounding this topic. 


\section{Interactive word tree}

In an effort to deepen the content analysis and to enrich this study's results analysis, the interactive word tree technique, operationalized by the MAXQDA software, was applied.

The word tree is composed of elements called roots, which are linked to other elements called leaves, allowing the identification of the semantic principles that determine the correlations observed in this literature review (MAXQDA, 2018). Consequently, the use of this technique provided both the visualization of the combinations that lead the IC concept within the selected articles for the scoping review and the semantic contexts importance, since the word size is proportional to its frequency in the texts (Figure 4).

From the structure of the word tree, it was observed that the keyword institutional capacity presents a multiplicity of actors, meanings, and instrumentalizations that involve its conceptual construction. It was found that studies on IC cover the three levels of the Brazilian government (federal, state and municipal), exposed by the DHC, as well as policies, programs and assessments of different government actions (social assistance, land management and planning, educational policies, etc.), corroborating the considerations presented by Huerta (2008) and Wu et al. (2015) about the need for studies on IC to combine all the components (subtypes and dimensions) of this capacity, in order to obtain a less subjective and/or related to certain research contexts explanation.

Therefore, this research revealed the lack of a global and consolidated theoretical framework that supports the theoretical-applied understanding of the IC concept and its specificities. However, this theme's great research potential to be explored further was also highlighted, especially in the governmental sphere, due to the multiplicity of government levels, actors and measurement instruments that cover the Institutional Capacity theme.

Finally, this study showed that the IC concept is associated with government actions, including its different levels, and can be understood as the set of institutional competencies necessary to achieve public objectives.

\section{CONCLUSION}

In view of the results of the scoping review, three main points were evidenced: the great potential for publishing studies on the IC theme in the national literature, the scope of the concept and its adaptability to different methodological approaches.

With all the information obtained through the content analysis of the 31 articles selected for the scoping review, it can be stated that: a) the State assumes a prominent role in studies on IC, an understandable situation due to the centrality of laws, decrees and norms from the 1988 Federal Constitution, found in the analysis of networks and through the interactive word tree technique; b) the national authors who dealt with the IC theme attributed a greater degree of importance to the administrative, political and fiscal dimensions; c) the authors, when studying and operationalizing the IC concept, do so in different research contexts with a view to explaining a particular/specific set of results (performance in education, health, tourism, etc.). Regarding the last observation, Lindvall and Teorell (2016) and Addison (2009) have previously indicated that understanding IC from specific approaches limits the application of this concept.

The results of this research converged with the international literature on IC by exposing the existence of multiple perspectives on the IC theme and the importance of conducting empirical research and theoretical essays in this field.

It is also important to stress that the arguments presented in this research were not empirically corroborated, hence the need to estimate the IC in a way that allows its examination in the different perspectives that circumscribe it. Another limitation was related to the impossibility of simultaneously analyzing texts written in Portuguese and English, limiting the results of this research.

Despite these limitations, this study supports the thesis that IC can be defined by government actions and comprises the set of capacities necessary to achieve its institutional objectives. Its empirical manifestation can be analyzed from a tripartite perspective, covering fiscal, administrative and political levels. It should be noted that such dimensions were considered relevant through the content analysis of the national publications on the IC theme.

For future research, it is suggested to analyze the degree of Brazilian states' IC, based on the dimensions explained by this research. 


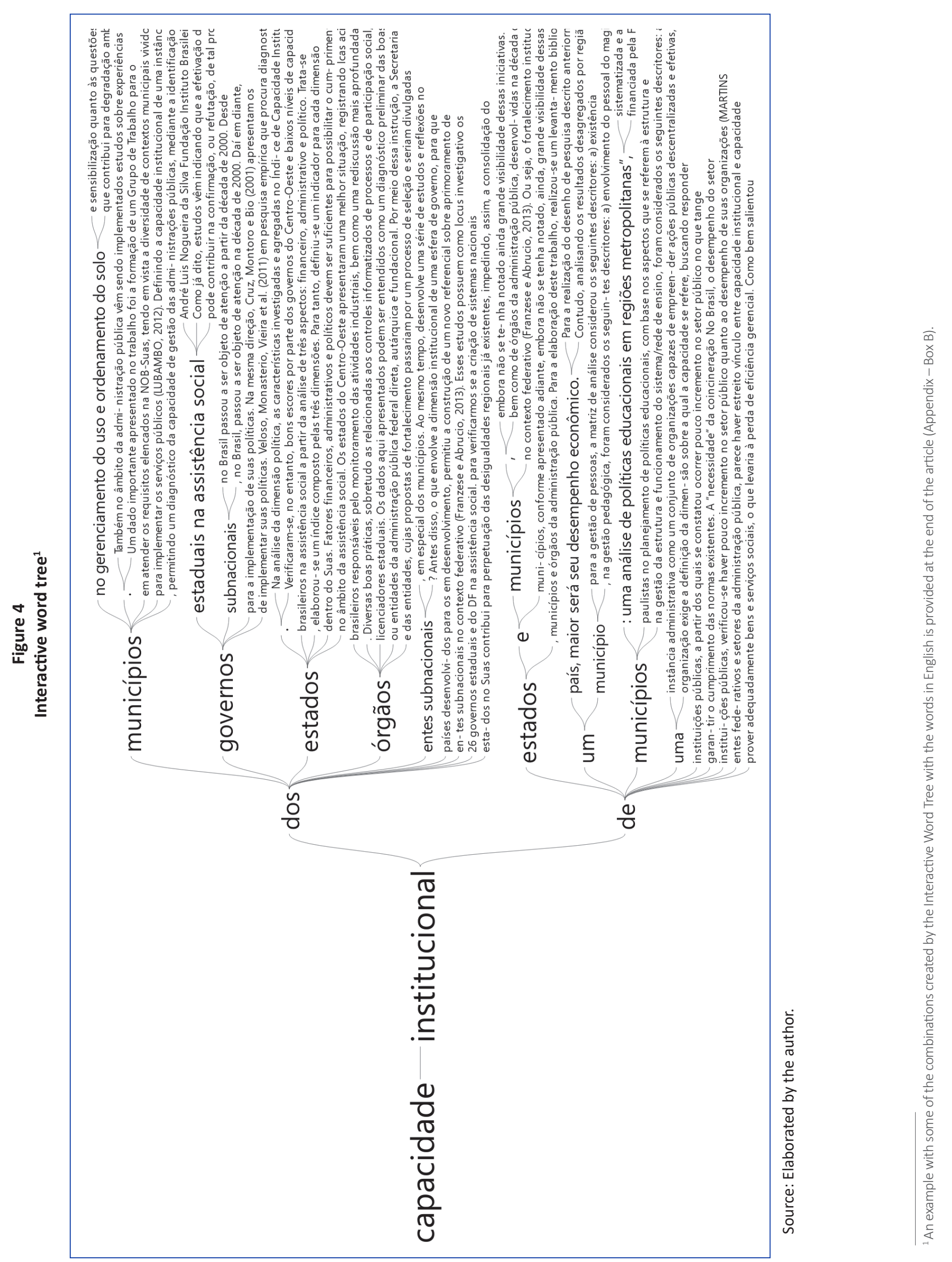




\section{REFERENCES}

Addison, H. J. (2009). Is administrative capacity a useful concept? Review of the application, meaning and observation of administrative capacity in political science literature applications of the concept of capacity. London, UK: London School of Economics.

Araújo, R. M., \& Posenatto, A. F. G. (2012). Plano de Fortalecimento da Gestão do Turismo (PFGT): uma avaliação ex ante no município de Nísia Floresta (RN). Revista de Administração Pública, 46(1), 221-248.

Arretche, M. (1999). Estado federativo e políticas sociais: determinantes da descentralização. Revista Brasileira de Ciências Sociais, 14(40), 111-141.

Arretche, M. (2004). Federalismo e políticas sociais no Brasil: problemas de coordenação e autonomia. São Paulo em Perspectiva, 18(2), 17-26.

Arretche, M., \& Marques, E. (2002). Municipalização da saúde no Brasil: diferenças regionais, poder do voto e estratégias de governo. Ciência \& Saúde Coletiva, 7(3), 455-479.

Azevedo, D. M., \& Miranda, F. A. N. (2012). Teoria das representações sociais e ALCESTE: contribuições teórico-metodológicas na pesquisa qualitativa. Saúde e Transformação Social, 3(4), 4-10.

Camargo, B. V., \& Justo, A. M. (2013). IRAMUTEQ: um software gratuito para análise de dados textuais. Temas em Psicologia, 21(2), 513-518.

Cavalcante, P. (2013). A competição eleitoral gera governos mais eficientes? Um estudo comparado das prefeituras no Brasil. Revista de Administração Pública, 47(6), 1569-1592.

Cingolani, L. (2013). The state of State capacity: a review of concepts, evidence and measures (UNU-MERIT Working Paper Series, n. 31). Maastricht, The Netherlands: United Nations University, Maastricht Economic and Social Research and Training Centre on Innovation and Technology.

Constituição da República Federativa do Brasil de 1988. (1988). Brasília, DF: Presidência da República. Retrieved from http://www. planalto.gov.br/ccivil_03/constituicao/constituicao.htm

Coordenação de Aperfeiçoamento de Pessoal de Nível Superior. (2018). Portal de periódicos CAPES. Retrieved from www.periodicos. capes.gov.br

Costa, J. M. B. S., Felisberto, E., Bezerra, L. C. A., Cesse, E. A. P., \& Samico, I. C. (2013). Monitoramento do desempenho da gestão da vigilância em saúde: instrumento e estratégias de uso. Ciência \& Saúde Coletiva, 18(5), 1201-1216.

Cruz, M. C. M. T., Montoro, F. A. F., Bio, S. R., Viana, M. T., Craveiro, S. S., \& Castro, T. P. (2011). Gestão pública no Estado de São Paulo: elementos para um olhar analítico. In J. F. A. Veloso, L. M. Monasterio, R. S. Vieira, \& R. B. Miranda (Orgs.), Gestão municipal no Brasil: um retrato das prefeituras (pp. 87-140). Brasília, DF: Instituto de Pesquisa Econômica Aplicada.

DeRouen, K., Jr., Ferguson, M. F., Norton, S., Park, Y. H., Lea, J., \& Streat-Bartlett, A. (2010). Civil war peace agreement implementation and State capacity. Journal of Peace Research, 47(3), 333-346.

Evans, P. (1995). Embedded autonomy: States and industrial transformation. Princeton, NJ: Princeton University Press.
Evans, P. B., Rueschmeyer, D., \& Skocpol, T. (2002). On the road toward a more understanding of the state. In P. B. Evans, D. Rueschmeyer, \& T. Skocpol (Eds.), Bringing the State Back In (pp. 347-366). Cambridge, UK: Cambridge University Press.

Evers, J. C. (2011). From the past into the future. How technological developments change our ways of data collection, transcription and analysis. Forum: Qualitative Social Research, 12(1), 1-31.

Fernandes, F. S. (2016). Capacidade institucional: uma revisão de conceitos e programas federais de governo para o fortalecimento da administração pública. Cadernos EBAPE.BR, 14(3), 695-704.

Gibbs, G. (2009). Análise de dados qualitativos. Porto Alegre, RS: Bookman.

Glosbe. (2018). Dicionário multilíngue. Retrieved from https:// pt.glosbe.com/

Gomes, S. (2010). The multi-faceted debate on decentralization and collective welfare. Brazilian Political Science Review, 4(2), 103-128.

Hanson, J. K., \& Sigman, R. (2013). Leviathans Latent Dimensions: Measuring State Capacity for Comparative Political Research. In Proceedings of the World Bank Political Economy Brown Bag Lunch Series, Washington, DC.

Hartley, K., \& Zhang, J. (2016). Measuring Policy Capacity Through Governance Indices. In X. Wu, M. Howlett, \& M. Ramesh (Eds.), Policy Capacity and Governance: Studies in the Political Economy of Public Policy (pp. 67-97). London, UK: Palgrave Macmillan.

Henderson, S., \& Segal, E. H. (2013). Visualizing qualitative data in evaluation research. New Directions for Evaluation, 139, 53-71.

Howlett, M. (2015). ScienceDirect Policy analytical capacity: the supply and demand for policy analysis in government. Policy and Society, 34(3-4), 173-182.

Huerta, R. A. (2008). Una ruta metodológica para evaluar la capacidad institucional. Política y Cultura, 30, 119-134.

Lessik, A., \& Michener, V. (2000). Measuring institutional capacity (Recent Practices in Monitoring and Evaluation Tips, n. 15). Washington, DC: International Development Cooperation Agency/United States Agency for International Development.

Levy, Y., \& Ellis, T. J. (2006). A system approach to conduct an effective literature review in support of information systems research. Informing Science Journal, 9, 181-212.

Lindvall, J., \& Teorell, J. (2016). State capacity as power: a conceptual framework. Lund: Department of Political Science, 16(1), 1-32.

Litvack, J., Ahmad, J., \& Bird, R. (1998). Rethinking decentralization in developing countries. Washington, DC: World Bank.

Lopes, S. A. (1997). A teia invisível. Informação e contra-informação nas redes de ONGs e movimentos sociais (Doctoral Dissertation). Universidade Federal do Rio de Janeiro, Rio de Janeiro, RJ.

Lubambo, C. W. (2002). Conselhos gestores e desempenho da gestão nos municípios: potencialidades e limites (Textos para Discussão, n. 149). Recife, PE: Fundação Joaquim Nabuco. 
Lubambo, C. W., \& Coutinho, H. G. (2004). Conselhos gestores e o processo de descentralização. São Paulo em Perspectiva, 18(4), 62-72.

MAXQDA. (2018). Qualitative data analysis software. Retrieved from http://www.maxqda.com/

Mizrahi, Y. (2004). Capacity enhancement indicator: review of the literature. Washington, DC: World Bank Institute.

Molina, J. L., Muños, J. M., \& Doménech, M. (2002). Redes de publicaciones científicas: un análisis de la estructura de coautorías. Revista Hispana para el Análisis de Redes Sociais, 1(3), 223-238.

Nascimento, A. R. A., \& Menandro, P. R. M. (2006). Análise lexical e análise de conteúdo: Uma proposta de utilização conjugada. Estudos e Pesquisas em Psicologia, 6(2), 72-88

Neitzk, A. C. A., Gonçalves, G. P, Oliveira, R. M., Machado, D. G., \& Gibbon, A. R. O. (2015). Custos ambientais: um estudo exploratório na Região Sul do Brasil. Revista de Gestão, Finanças e Contabilidade, 5(2), 71-86.

Oates, W. E. (1999). An essay on fiscal federalism. Journal of Economic Literature, 37(3), 1120-1149.

Painter, M., \& Pierre, J. (2005). Unpacking policy capacity: issues and themes. In M. Painter, \& J. Pierre (Eds.), Challenges to State policy capacity (pp. 1-18). New York, NY: Palgrave Macmillan.

Pallotti, P. L. M., \& Costa, B. L. D. (2011). Relações intergovernamentais e descentralização. Revista de Sociologia e Política, 19(39), 211-235.

Pedroso, B., \& Pilatti, L. (2009). O novo Qualis: perspectivas para a pós-graduação em engenharia de produção. Revista Gestão Industrial, 5(2), 44-60.

Peterson, J., Pearce, P. F., Ferguson, L. A., \& Langford, C. A. (2017). Understanding scoping reviews: definition, purpose, and process. Journal of the American Association of Nurse Practitioners, 29(1), 12-16.

Ramos, A., Faria, M., \& Faria, A. (2014). Systematic review: contribution to innovation in educational research. Revista Diálogo Educacional, 14(41), 17-36.

Ratinaud, P., \& Marchand, P. (2012). Application de la méthode ALCESTE aux (gros), corpus et stabilité des (mondes lexicaux): analyse du (cablegate) avec IRAMUTEQ. In Annales de 11ㅇo Journées Internationales D’Analyse Statistique des Données Textuelles, Liège, Belgic.

Romancini, R. (2010). O que é uma citação? A análise de citações na ciência. Intexto, 2(12), 20-35.

Rumrill, P. D., Fitzgerald, S. M., \& Merchant, W. R. (2010). Using scoping literature reviews as a means of understanding and interpreting existing literature. IOS Press, 35, 399-404.
Saillard, E. K. (2011). Systematic versus interpretive analysis with two CAQDAS packages: NVivo and MAXQDA. Forum: Qualitative Social Research, 12(1), 1-21.

Silva, A. L. N. (2015). Os estados no SUAS: uma análise da capacidade institucional dos governos estaduais na assistência social. Revista de Administração Pública, 49(5), 1167-1192.

Silva, E. P. S., Fonseca, E. S., Mafra, S. C. T., \& Freitas, N. C. (2016). O idoso no contexto familiar: uma abordagem a partir do banco de dados da Capes. Sociedade em Debate, 22(2), 299-318.

Silva, L., Cunha, M., Domingos, A. \& Torres, M. (2015). Instituições políticas e desenvolvimento econômico: evidências de um estudo empírico? Revista Estudos Institucionais, 1(1), 1-28.

Skocpol, T. (1985). Bringing the State back. In P. Evans, D. Rueschemeyer, \& T. Skocpol (Ed.), Strategies of analysis in current research (pp. 3-43). Cambridge, UK: Cambridge University Press.

Soares, M. (1989). Alfabetização no Brasil: o estado do conhecimento. Brasília, DF: Instituto Nacional de Estudos e Pesquisas Educacionais Anísio Teixeira/Ministério da Educação.

Souza, C. (2005). Federalismo, desenho contitucional e instituições federativas no Brasil pós-1988. Revista de Sociologia e Política, 24, 105-121.

Veloso, J. F. A., Monasterio, L. M., Vieira, R. S., \& Miranda, R. B. (2011). Uma visão inicial dos subsistemas da gestão pública municipal. In J. F. A. Veloso, L. M. Monasterio, R. S. Vieira, \& R. B. Miranda (Orgs.), Gestão municipal no Brasil: um retrato das prefeituras (pp. 11-40). Brasília, DF: Instituto de Pesquisa Econômica Aplicada.

Vidal, J. P. (2014). A Defensoria Pública do Estado do Pará: uma observação sistêmica da capacidade institucional. Revista de Administração Pública, 48(3), 667-694.

Wasserman, S., \& Faust, K. (1994). Social network analysis. Cambridge, UK: Cambridge University Press.

Wattenberg, M., \& Viégas, F. (2008). The word tree, an interactive visual concordance. IEEE Transaction on Visualization and Computer Graphics, 14(6), 1221-1228.

Wu, X., Ramesh, M., \& Howlett, M. (2015). Policy capacity: a conceptual framework for understanding policy competences and capabilities. Policy and Society, 34(3-4),165-171.

Zampier, M. B. (2007). Movimentos sociais, apropriação das tecnologias da informação e comunicação e a centralidade na rede da Coordinadora Latinoamericana de Organizaciones del Campo (Master Thesis). Universidade Federal de Viçosa, Viçosa, MG.

Douglas Gomes Martins

ORCID: https://orcid.org/0000-0002-9883-6716

Master and Professor in Administration at IFPA/Campus Paragominas. E-mail: dougmartins08@gmail.com 


\section{APPENDIX}

\begin{tabular}{|c|c|c|c|c|c|c|}
\hline 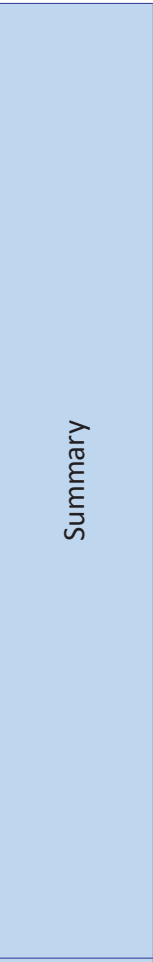 & 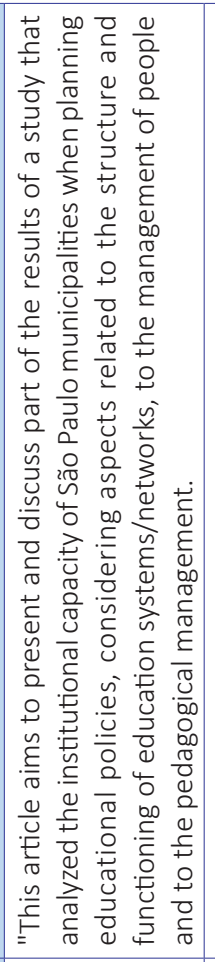 & 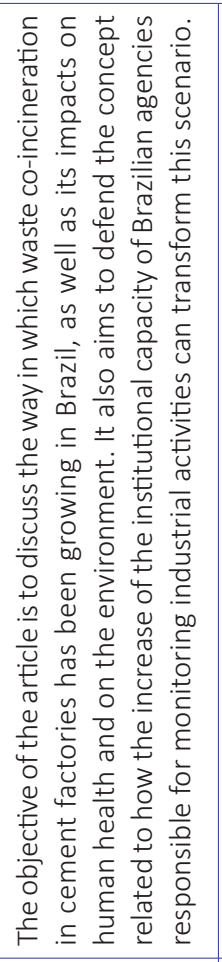 & 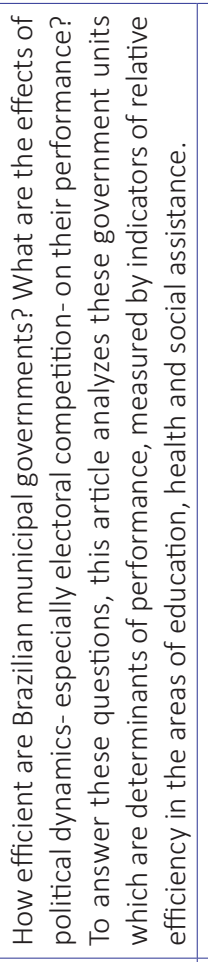 & 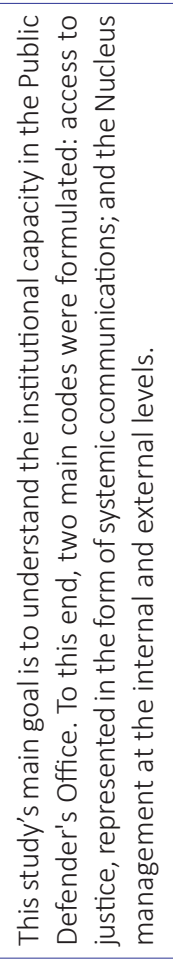 & 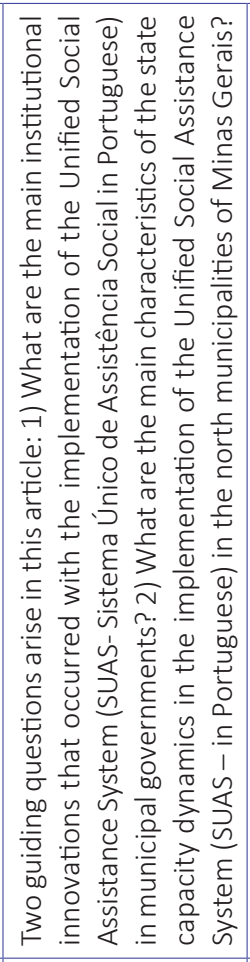 & 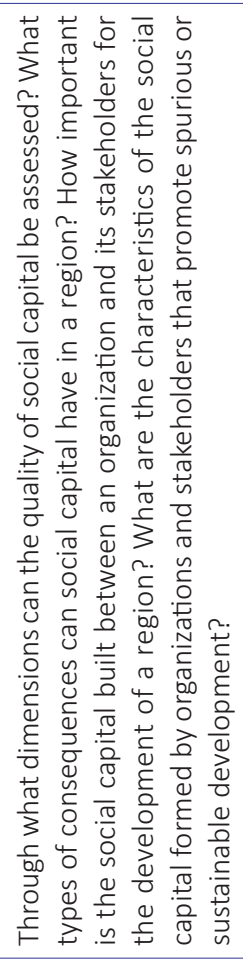 \\
\hline 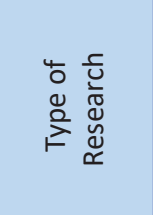 & 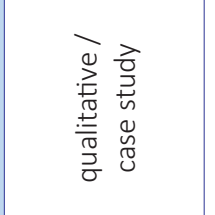 & 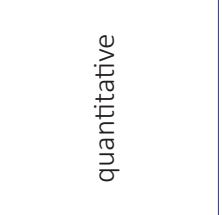 & 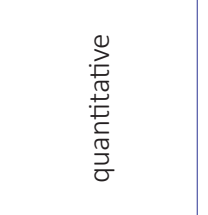 & 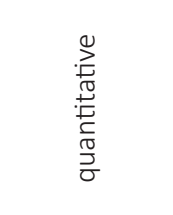 & 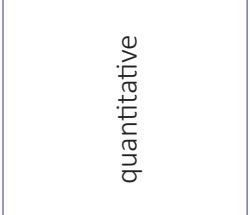 & 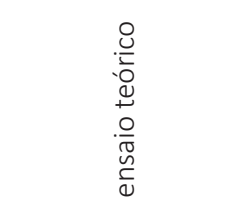 \\
\hline 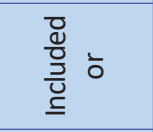 & $\begin{array}{l}\frac{\bar{d}}{\mathrm{~d}} \\
\frac{\mathrm{g}}{\mathrm{g}} \\
. \underline{\underline{y}}\end{array}$ & $\begin{array}{l}\bar{g} \\
\frac{d}{0} \\
\bar{g} \\
. \underline{\underline{y}}\end{array}$ & $\begin{array}{l}\frac{0}{d} \\
\frac{d}{9} \\
\underline{\underline{y}} \\
\underline{\underline{y}}\end{array}$ & 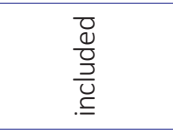 & 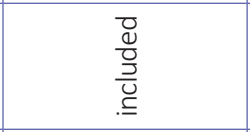 & 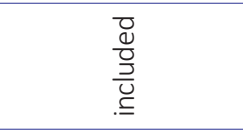 \\
\hline 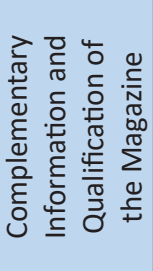 & 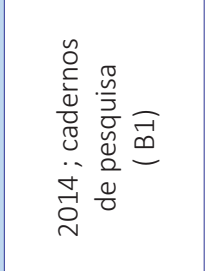 & 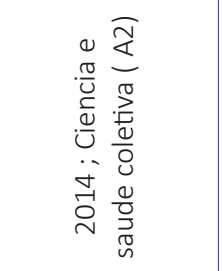 & 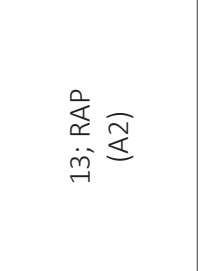 & 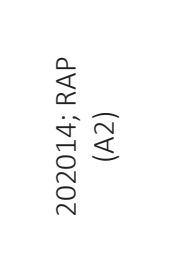 & 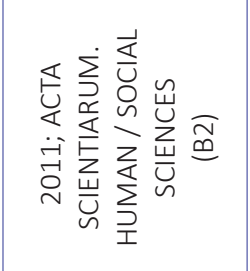 & 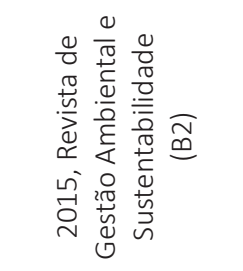 \\
\hline 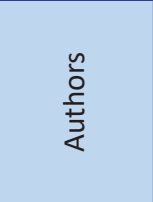 & 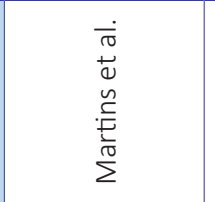 & 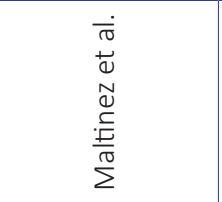 & 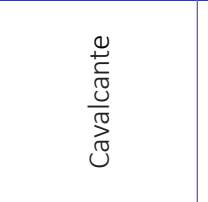 & $\begin{array}{l}\frac{\pi}{0} \\
\frac{0}{2}\end{array}$ & 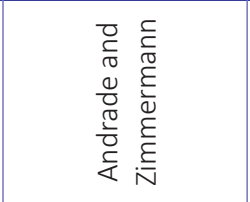 & 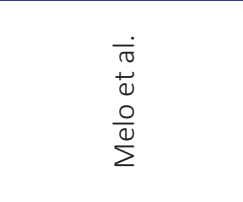 \\
\hline 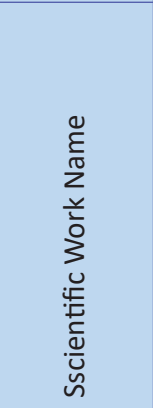 & 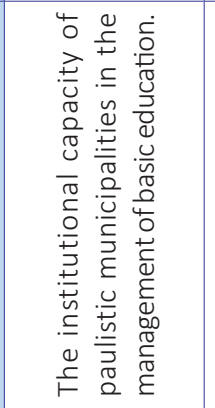 & 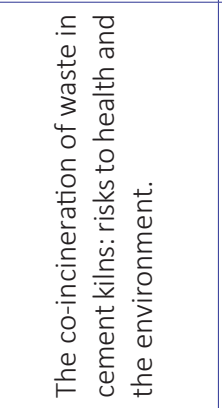 & 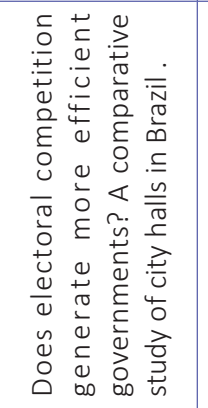 & 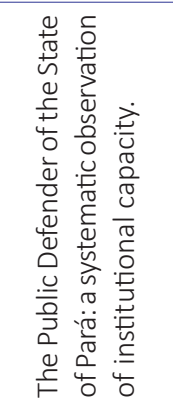 & 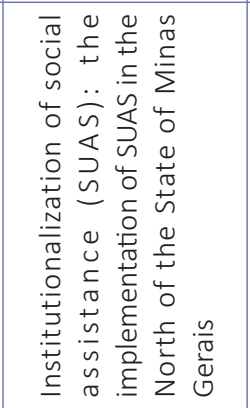 & 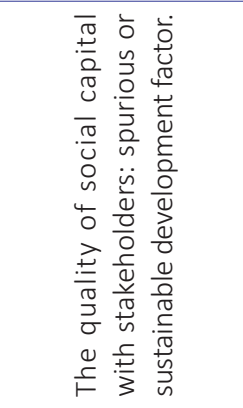 \\
\hline 으 & $\dashv$ & $\sim$ & $m$ & 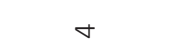 & เn & 0 \\
\hline
\end{tabular}




\begin{tabular}{|c|c|c|c|c|c|c|}
\hline 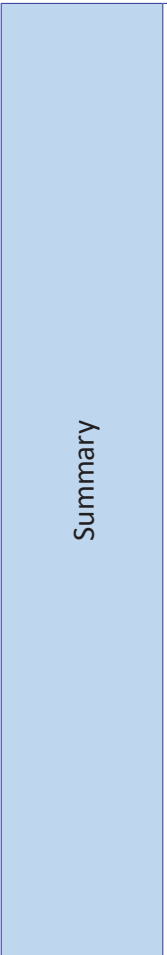 & 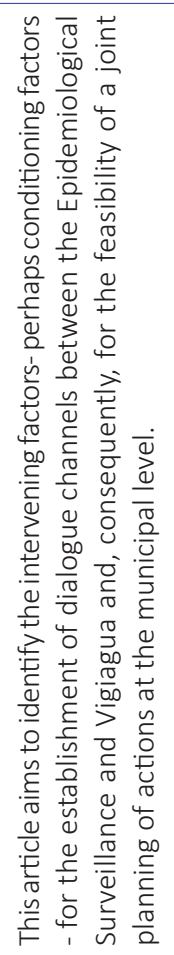 & 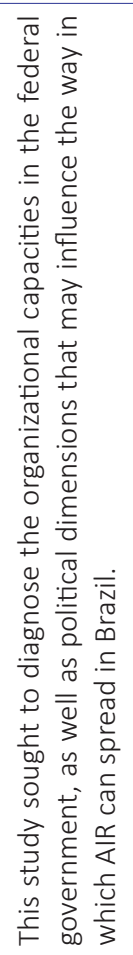 & 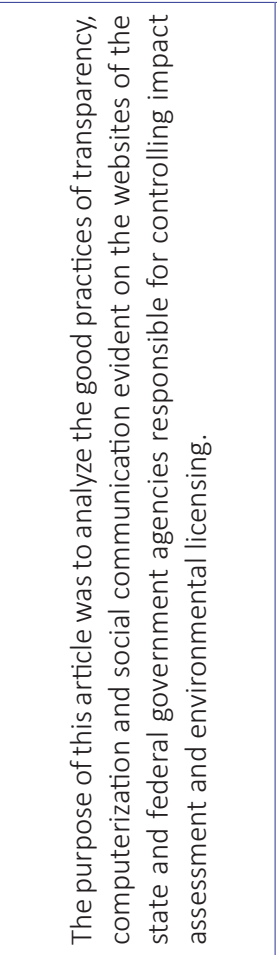 & 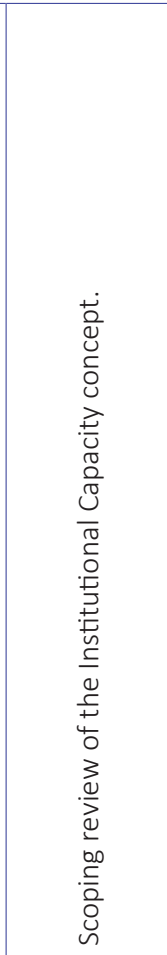 & 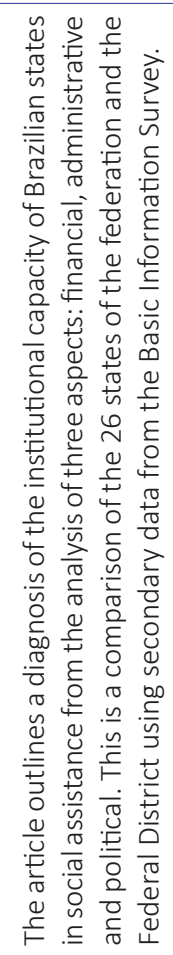 & 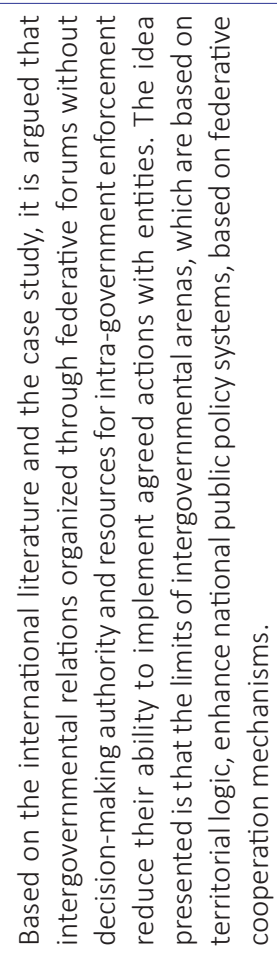 \\
\hline 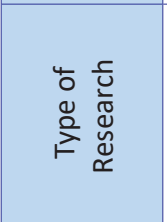 & 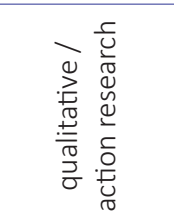 & 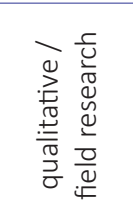 & 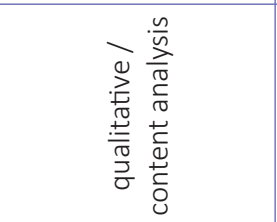 & 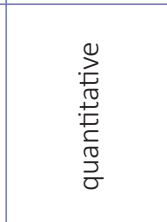 & 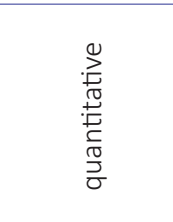 & 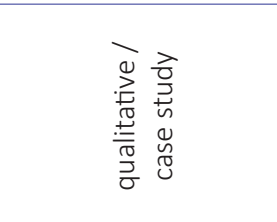 \\
\hline$\frac{\bar{g}}{\frac{d}{\frac{d}{3}}} \bar{o}$ & 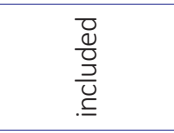 & 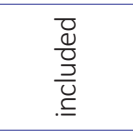 & 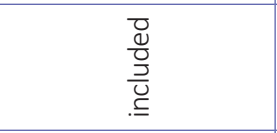 & $\begin{array}{l}\frac{\bar{g}}{\mathrm{~d}} \\
\frac{\mathrm{g}}{\mathrm{g}} \\
. \underline{\underline{y}}\end{array}$ & $\begin{array}{l}\frac{\bar{g}}{\mathrm{~d}} \\
\mathrm{~g} \\
\underline{\underline{g}} \\
\underline{\underline{I}}\end{array}$ & $\begin{array}{l}\frac{\bar{g}}{d} \\
\frac{\mathrm{d}}{\mathrm{g}} \\
\underline{\underline{g}}\end{array}$ \\
\hline 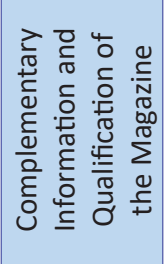 & 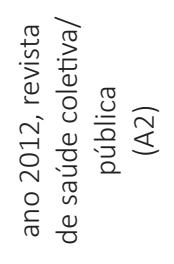 & 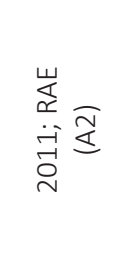 & 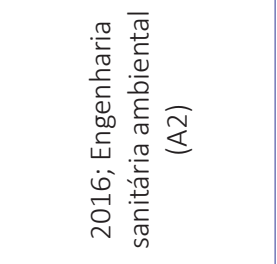 & 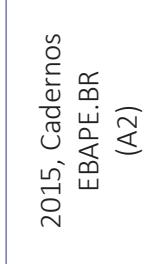 & 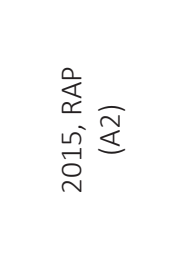 & 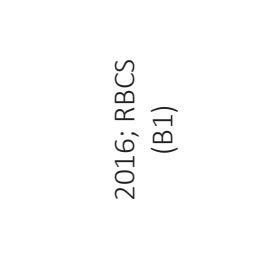 \\
\hline 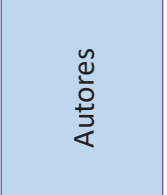 & 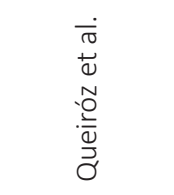 & $\begin{array}{l}\overline{\mathbb{U}} \\
\alpha\end{array}$ & 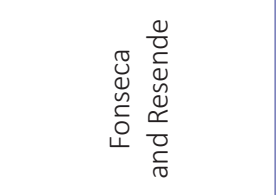 & 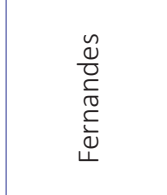 & $\sum_{i \bar{n}}^{\frac{\pi}{2}}$ & 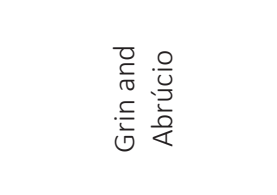 \\
\hline 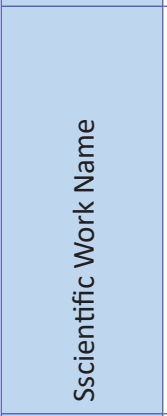 & 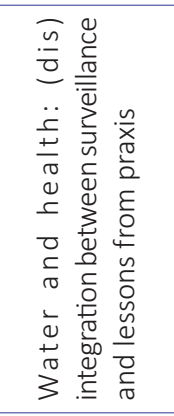 & 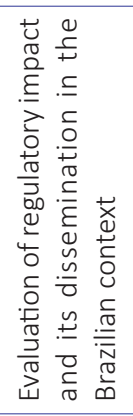 & 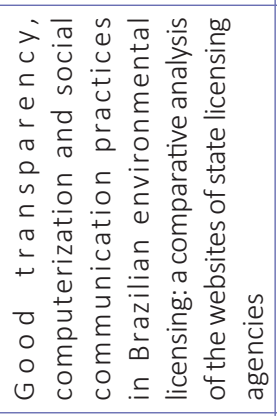 & 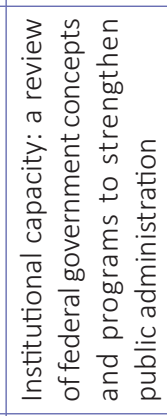 & 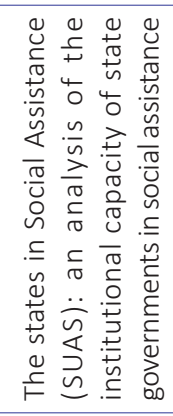 & 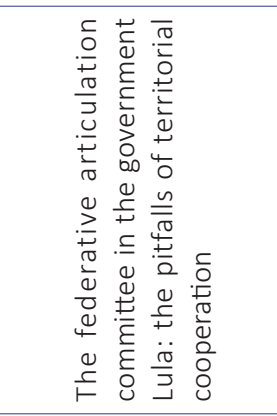 \\
\hline 으 & $\wedge$ & $\infty$ & $\sigma$ & 아 & $\vec{G}$ & $\underset{\sim}{\sim}$ \\
\hline
\end{tabular}




\begin{tabular}{|c|c|c|c|c|}
\hline 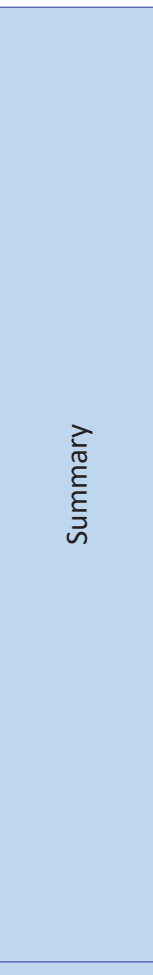 & 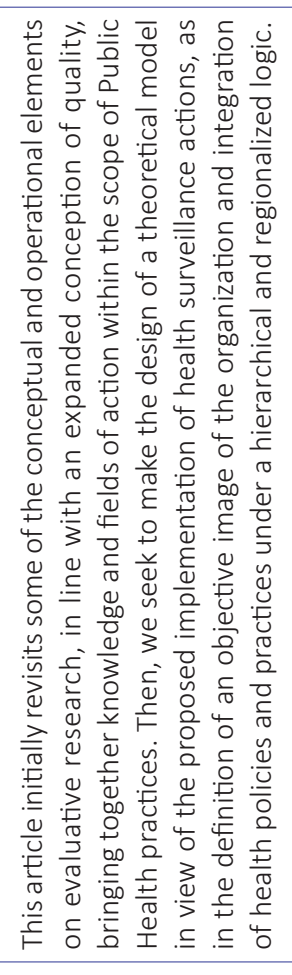 & 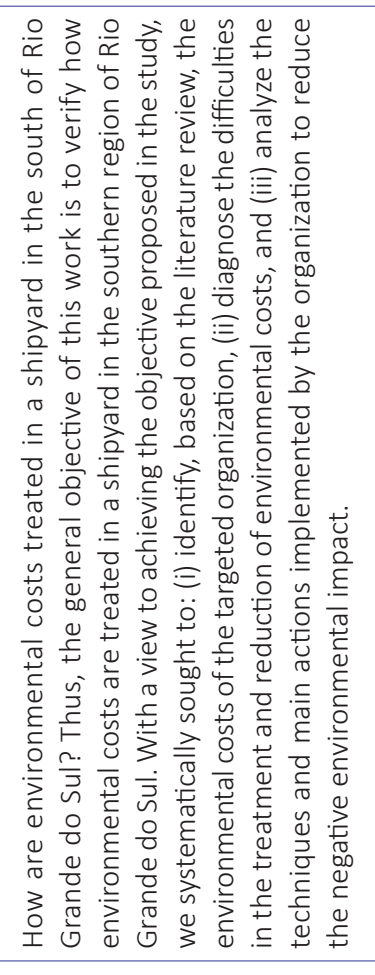 & 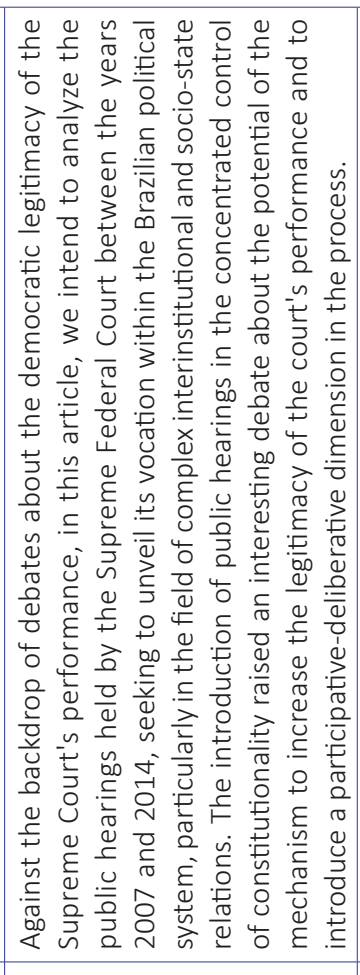 & 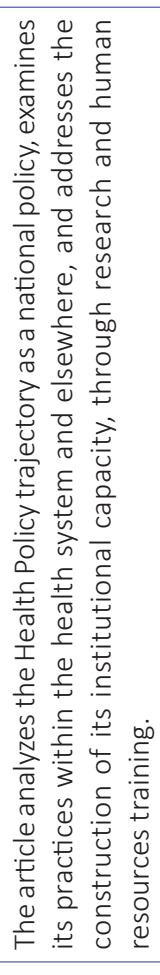 \\
\hline 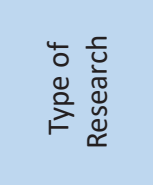 & 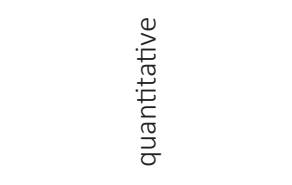 & 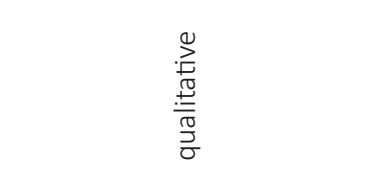 & 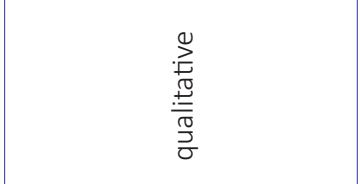 & 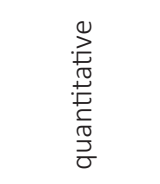 \\
\hline 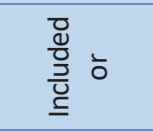 & $\begin{array}{l}\frac{\bar{g}}{d} \\
\frac{d}{\bar{g}} \\
\underline{\underline{y}}\end{array}$ & $\begin{array}{l}\frac{\bar{g}}{\mathrm{~d}} \\
\frac{\mathrm{g}}{\mathrm{g}} \\
\underline{\underline{y}}\end{array}$ & $\begin{array}{l}\frac{\bar{g}}{\mathrm{~d}} \\
\frac{\mathrm{g}}{\mathrm{g}} \\
\underline{\underline{y}}\end{array}$ & $\begin{array}{l}\frac{\bar{g}}{\frac{d}{0}} \\
\frac{\bar{g}}{\underline{y}} \\
. \leq\end{array}$ \\
\hline 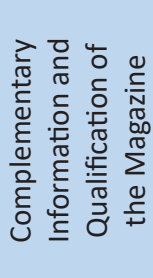 & 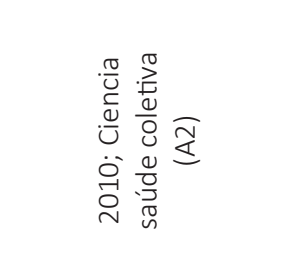 & 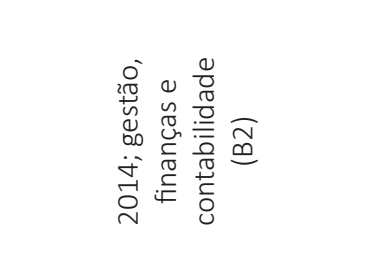 & 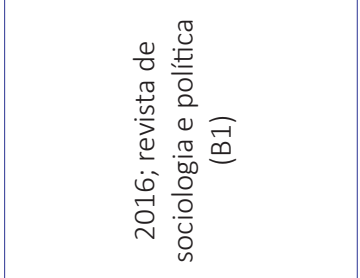 & 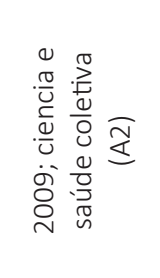 \\
\hline 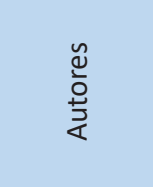 & 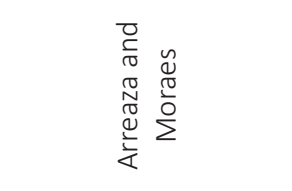 & 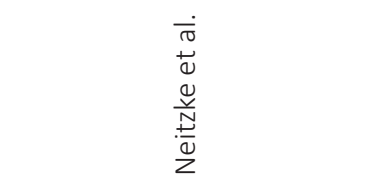 & 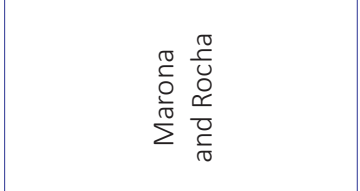 & 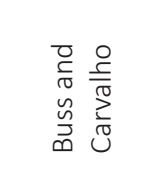 \\
\hline 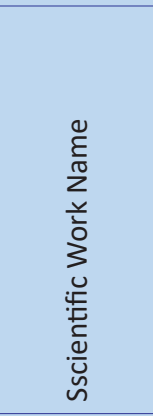 & 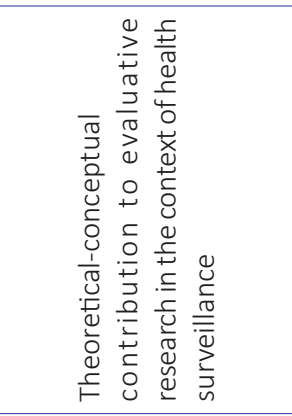 & 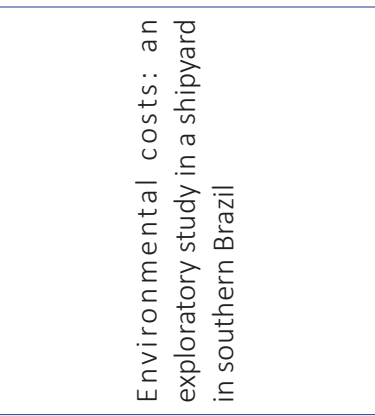 & 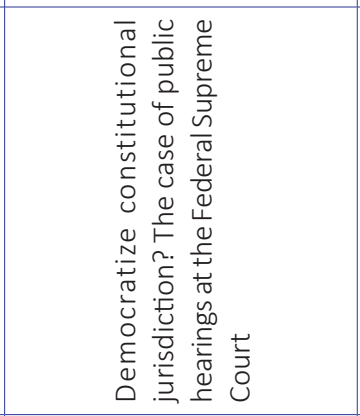 & 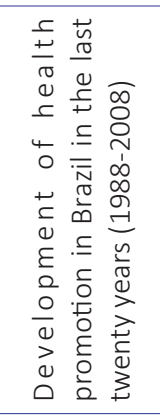 \\
\hline ㅇ & $\stackrel{m}{\rightarrow}$ & 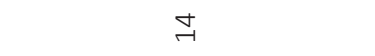 & $\stackrel{\sim}{\sim}$ & $\underset{\sim}{\mathscr{1}}$ \\
\hline
\end{tabular}




\begin{tabular}{|c|c|c|c|c|c|}
\hline $\begin{array}{l}\frac{7}{0} \\
\stackrel{0}{0} \\
\frac{\text { है }}{J} \\
\sim\end{array}$ & 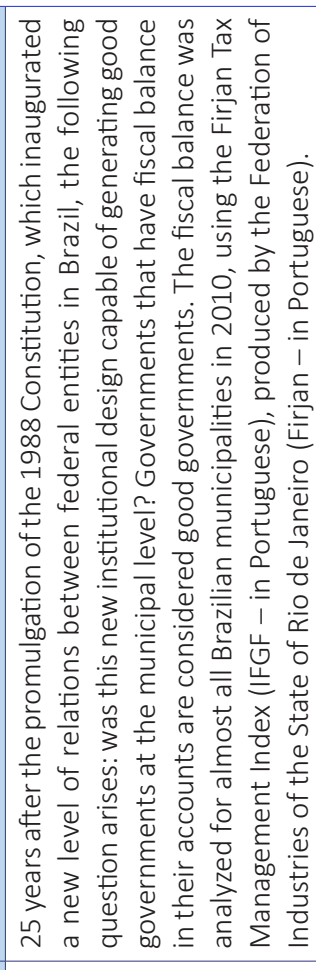 & 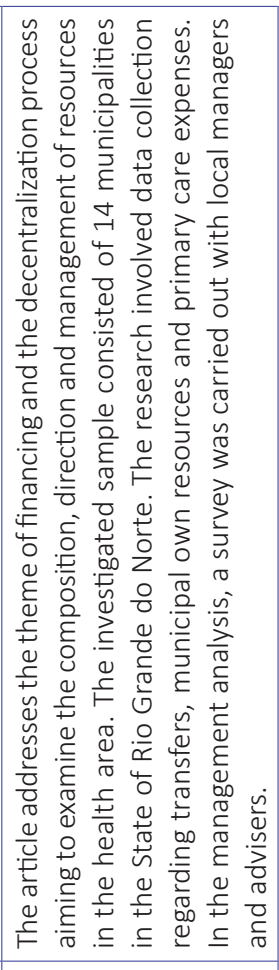 & 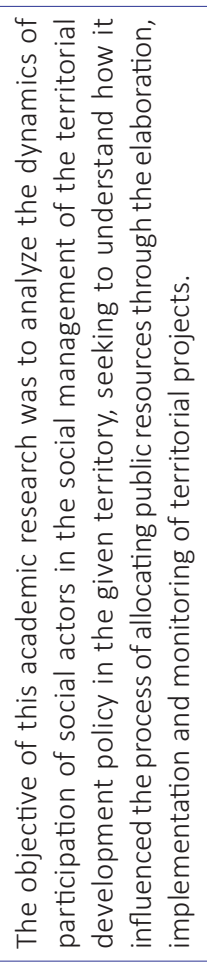 & 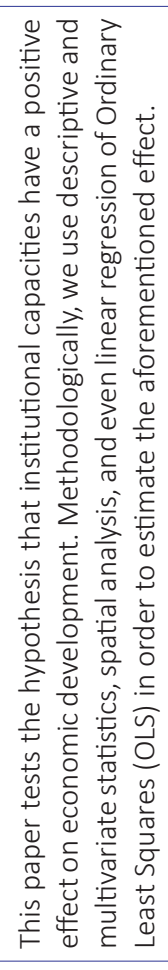 & 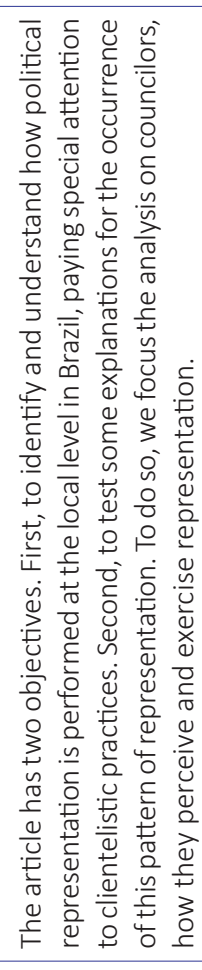 \\
\hline 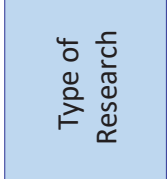 & 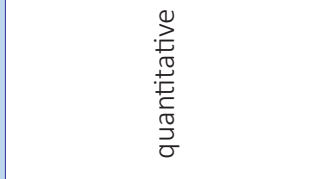 & 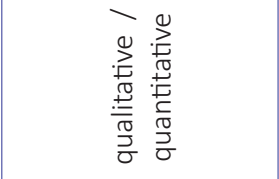 & 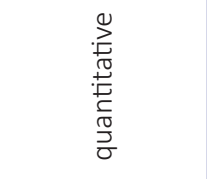 & 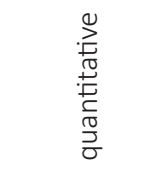 & 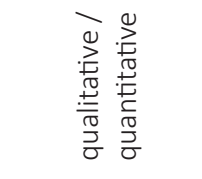 \\
\hline$\frac{\text { 엉 }}{\frac{0}{0}}$ & $\begin{array}{l}\bar{D} \\
\frac{d}{0} \\
\frac{\partial}{U} \\
. \subseteq\end{array}$ & $\begin{array}{l}\frac{\bar{d}}{0} \\
\frac{0}{0} \\
. \underline{0}\end{array}$ & $\begin{array}{l}\bar{d} \\
\frac{d}{0} \\
\frac{\partial}{U} \\
. \subseteq\end{array}$ & $\begin{array}{l}\frac{0}{0} \\
\frac{0}{3} \\
.0 \\
.0\end{array}$ & $\begin{array}{l}\frac{D}{d} \\
\frac{0}{0} \\
\frac{D}{U} \\
. \subseteq\end{array}$ \\
\hline 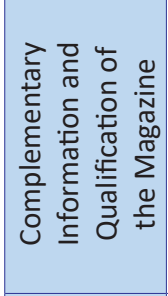 & 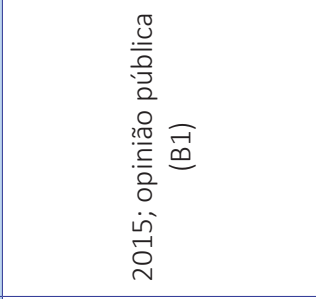 & 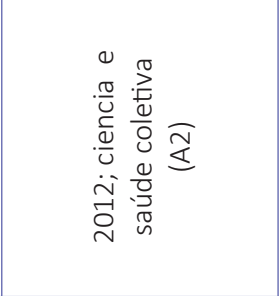 & 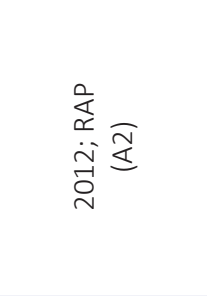 & 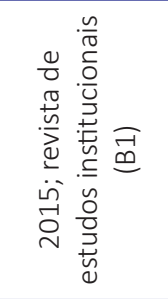 & 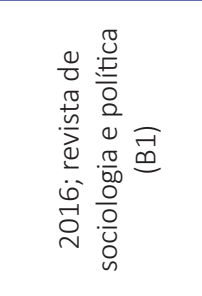 \\
\hline $\begin{array}{l}\tilde{y} \\
\frac{0}{0} \\
\stackrel{3}{4}\end{array}$ & 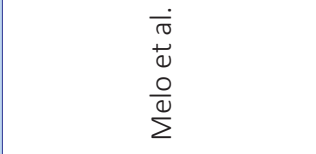 & 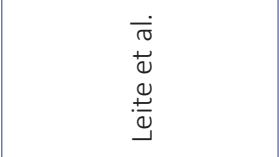 & $\begin{array}{l}\frac{\dot{0}}{\pi} \\
+0 \\
\frac{0}{\pi} \\
\frac{\pi}{\pi}\end{array}$ & 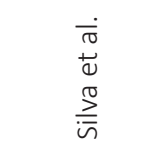 & 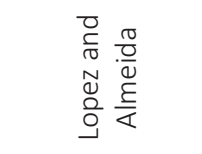 \\
\hline 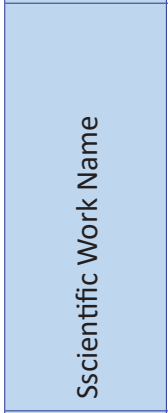 & 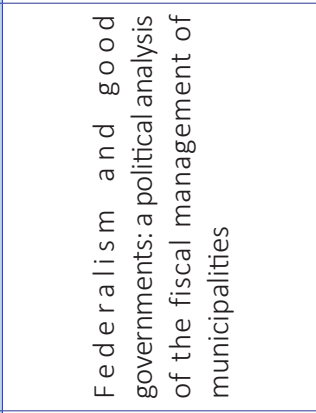 & 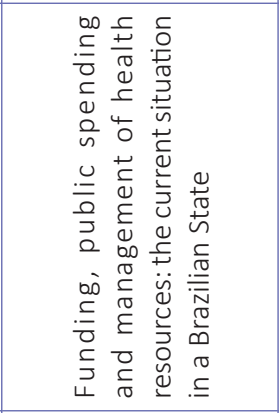 & 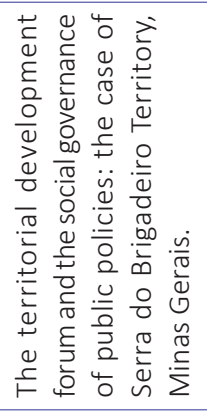 & 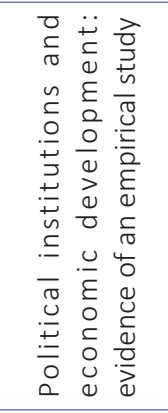 & 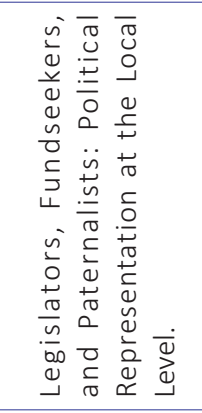 \\
\hline 으 & ને & $\stackrel{\infty}{\sim}$ & $\underset{\sim}{\sigma}$ & 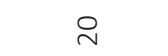 & $\vec{\sim}$ \\
\hline
\end{tabular}




\begin{tabular}{|c|c|c|c|c|c|c|}
\hline 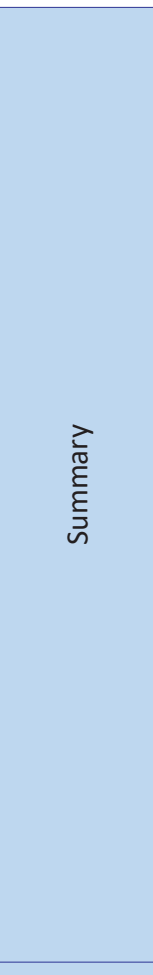 & 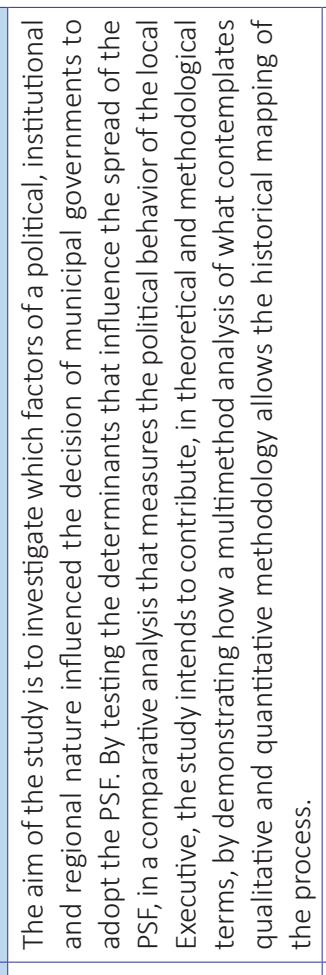 & 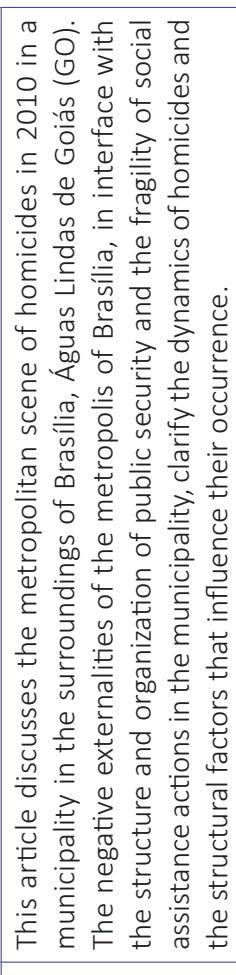 & 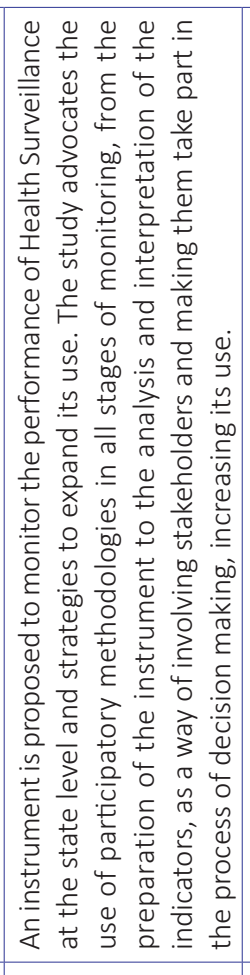 & 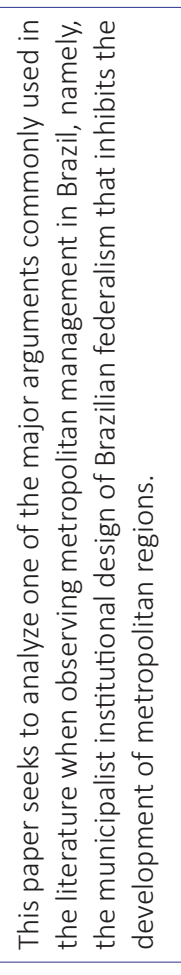 & 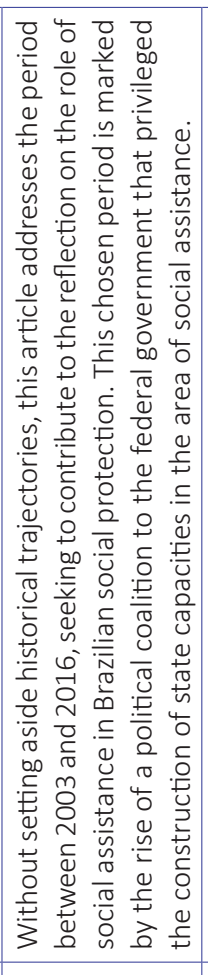 & 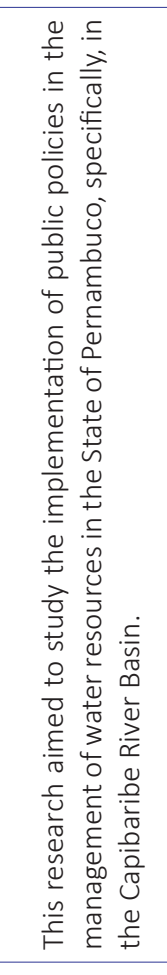 \\
\hline 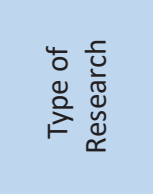 & 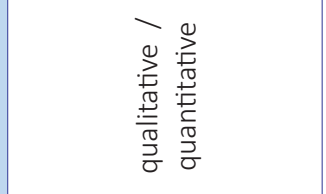 & 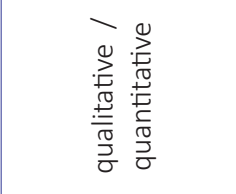 & 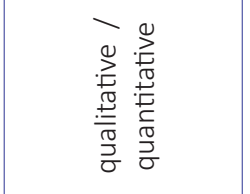 & 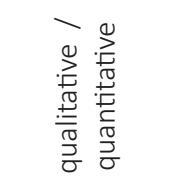 & 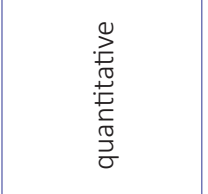 & 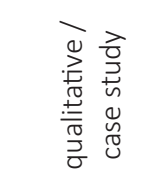 \\
\hline 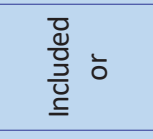 & $\begin{array}{l}\bar{g} \\
\frac{\mathbb{d}}{\bar{g}} \\
\underline{\underline{G}}\end{array}$ & $\begin{array}{l}\bar{g} \\
\frac{\vec{d}}{\underline{g}} \\
\underline{\underline{G}}\end{array}$ & $\begin{array}{l}\bar{g} \\
\frac{d}{g} \\
\frac{\vec{v}}{\underline{S}}\end{array}$ & 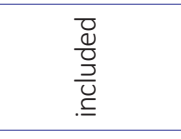 & $\begin{array}{l}\frac{\bar{g}}{\mathrm{~d}} \\
\frac{\mathrm{g}}{\mathrm{g}} \\
.\end{array}$ & $\begin{array}{l}\frac{\bar{g}}{\mathrm{~d}} \\
\frac{\mathrm{g}}{\mathrm{g}} \\
\end{array}$ \\
\hline 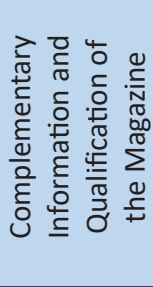 & 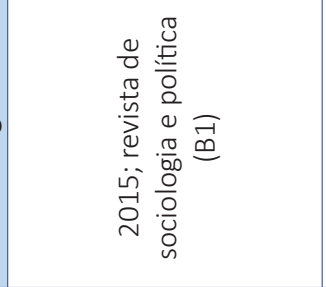 & 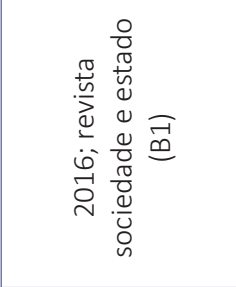 & 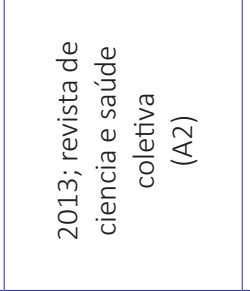 & 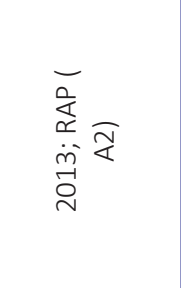 & 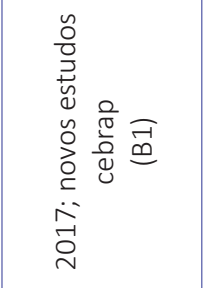 & 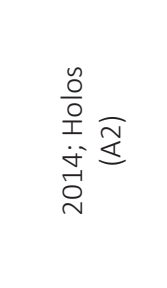 \\
\hline 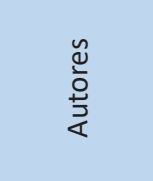 & 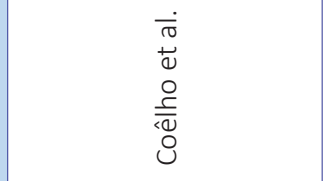 & 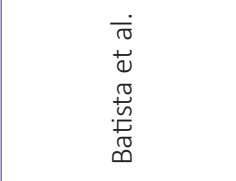 & 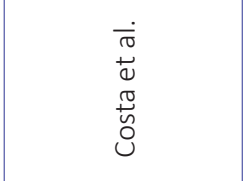 & 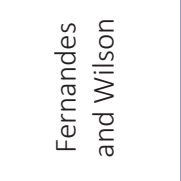 & 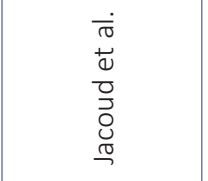 & $\begin{array}{l}\stackrel{\infty}{2} \\
\dot{\bar{n}} \\
0 \\
\frac{\pi}{3} \\
\dot{\bar{n}}\end{array}$ \\
\hline 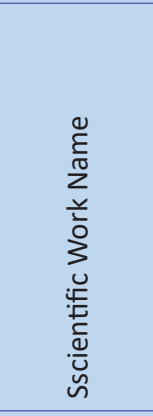 & 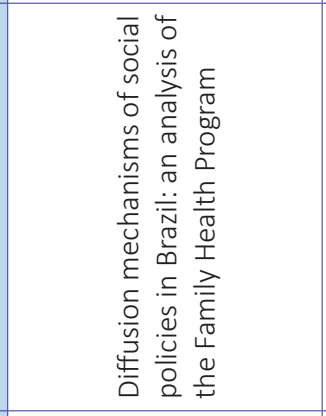 & 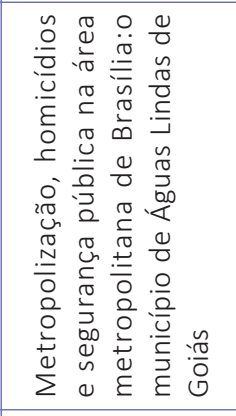 & 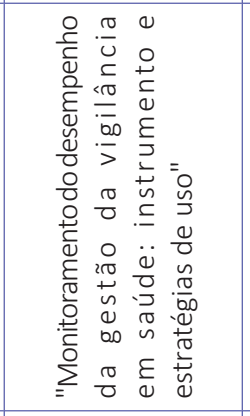 & 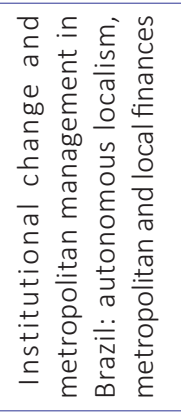 & 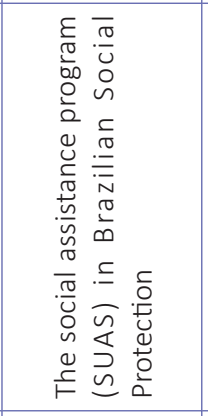 & 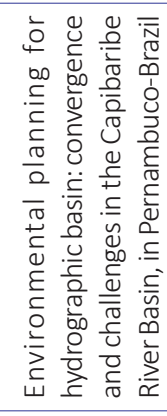 \\
\hline ㅇ & $\approx$ & $\stackrel{m}{\sim}$ & $\stackrel{\searrow}{\sim}$ & $\stackrel{\sim}{\sim}$ & $\stackrel{\bullet}{\sim}$ & 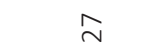 \\
\hline
\end{tabular}




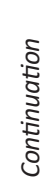

\begin{tabular}{|c|c|c|c|c|}
\hline 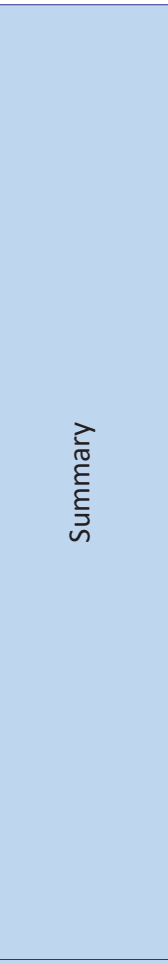 & 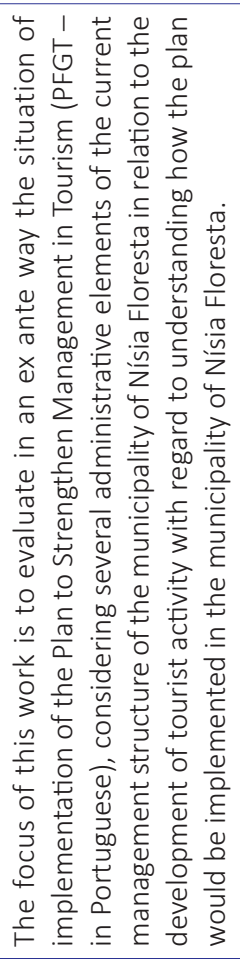 & 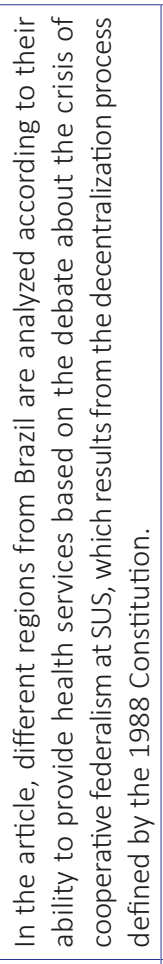 & 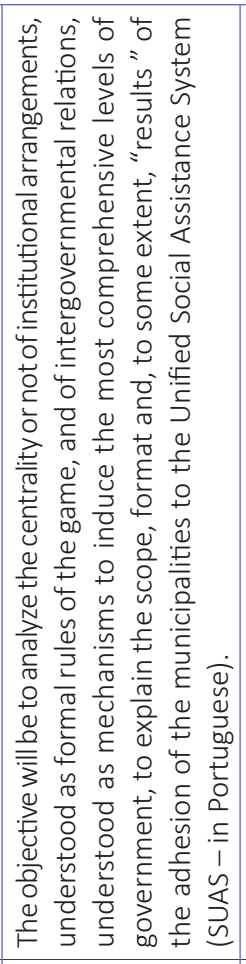 & 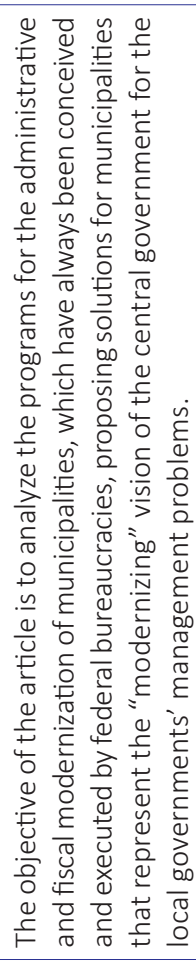 \\
\hline 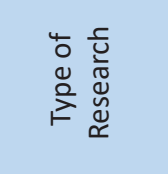 & 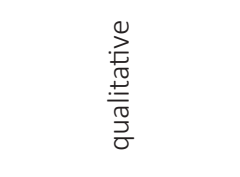 & 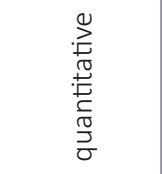 & 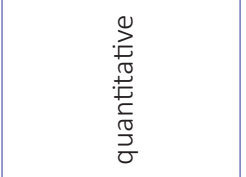 & 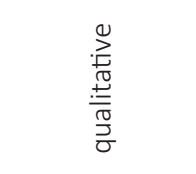 \\
\hline$\frac{\bar{d}}{\frac{d}{0}} \frac{1}{\underline{\underline{y}}}$ & $\begin{array}{l}\frac{D}{d} \\
\frac{0}{0} \\
\underline{\underline{U}} \\
. \underline{E}\end{array}$ & $\begin{array}{l}\frac{D}{d} \\
\frac{0}{O} \\
\frac{J}{U}\end{array}$ & $\begin{array}{l}\bar{d} \\
\frac{d}{0} \\
\frac{D}{0} \\
. \underline{I}\end{array}$ & 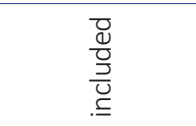 \\
\hline 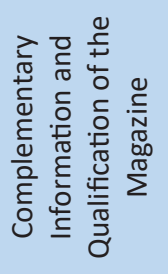 & 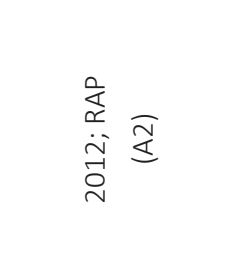 & 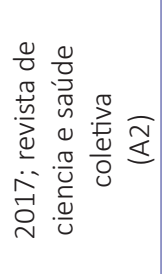 & 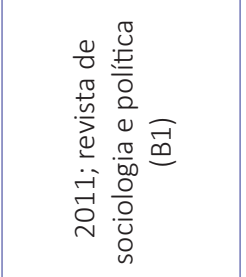 & 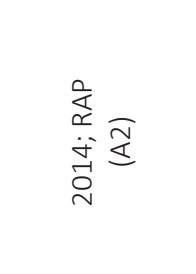 \\
\hline 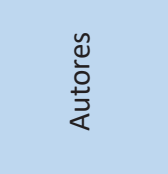 & 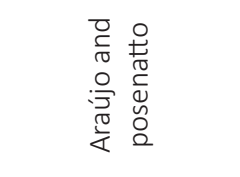 & 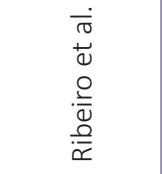 & 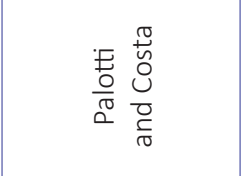 & · \\
\hline 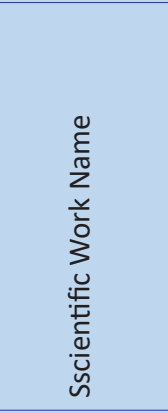 & 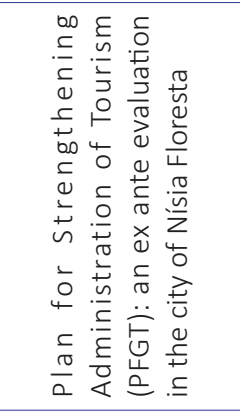 & 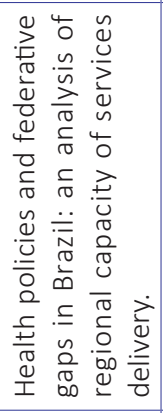 & 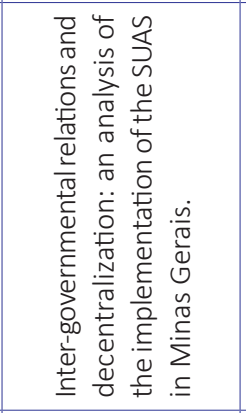 & 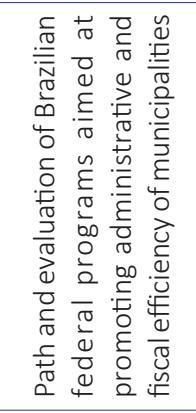 \\
\hline 으 & $\stackrel{\infty}{\sim}$ & શิ & ○ & $\vec{m}$ \\
\hline
\end{tabular}

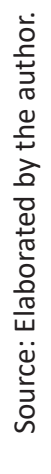

